\title{
How modelling paradigms affect simulated future land use change
}

\author{
Calum Brown ${ }^{1}$, Ian Holman ${ }^{2}$, and Mark Rounsevell ${ }^{1,3}$ \\ ${ }^{1}$ Institute of Meteorology and Climate Research, Atmospheric Environmental Research (IMK-IFU), \\ Karlsruhe Institute of Technology, Kreuzeckbahnstraße 19, 82467 Garmisch-Partenkirchen, Germany \\ ${ }^{2}$ School of Water, Energy and Environment, Cranfield University, Vincent Building, Bedford MK43 0AL, UK \\ ${ }^{3}$ School of Geosciences, University of Edinburgh, Edinburgh EH8 9XP, UK \\ Correspondence: Calum Brown (calum.brown@kit.edu)
}

Received: 6 July 2020 - Discussion started: 6 August 2020

Revised: 17 January 2021 - Accepted: 19 January 2021 - Published: 23 February 2021

\begin{abstract}
Land use models operating at regional to global scales are almost exclusively based on the single paradigm of economic optimisation. Models based on different paradigms are known to produce very different results, but these are not always equivalent or attributable to particular assumptions. In this study, we compare two pan-European integrated land use models that utilise the same climatic and socio-economic scenarios but which adopt fundamentally different modelling paradigms. One of these is a constrained optimising economicequilibrium model, and the other is a stochastic agent-based model. We run both models for a range of scenario combinations and compare their projections of spatially aggregate and disaggregate land use changes and ecosystem service supply levels in food, forest and associated environmental systems. We find that the models produce very different results in some scenarios, with simulated food production varying by up to half of total demand and the extent of intensive agriculture varying by up to $25 \%$ of the EU land area. The agentbased model projects more multifunctional and heterogeneous landscapes in most scenarios, providing a wider range of ecosystem services at landscape scales, as agents make individual, time-dependent decisions that reflect economic and non-economic motivations. This tendency also results in food shortages under certain scenario conditions. The optimisation model, in contrast, maintains food supply through intensification of agricultural production in the most profitable areas, sometimes at the expense of land abandonment in large parts of Europe. We relate the principal differences observed to underlying model assumptions and hypothesise that optimisation may be appropriate in scenarios that allow for coherent political and economic control of land systems, but not in scenarios in which economic and other scenario conditions prevent the changes in prices and responses required to approach economic equilibrium. In these circumstances, agent-based modelling allows explicit consideration of behavioural processes, but in doing so it provides a highly flexible account of land system development that is harder to link to underlying assumptions. We suggest that structured comparisons of parallel and transparent but paradigmatically distinct models are an important method for better understanding the potential scope and uncertainties of future land use change, particularly given the substantive differences that currently exist in the outcomes of such models.
\end{abstract}




\section{Introduction}

Computational models of the land system make essential contributions to the exploration of environmental and socioeconomic changes, supporting efforts to limit climate change and reverse biodiversity loss (Harrison et al., 2018; Rogelj et al., 2018). Such models are particularly useful for exploring conditions that do not currently exist and therefore cannot be observed, as well as for understanding past and present land use impacts (Filatova et al., 2016; Smith et al., 2019). As a result, the scope and complexity of land system models have been steadily increasing, with many now representing multiple land sectors (e.g. agriculture, forestry and urbanisation) within an Earth system context (e.g. incorporating economic, climatic, hydrological and energy systems) (Harrison et al., 2016; Kling et al., 2017; Pongratz et al., 2018).

Nevertheless, simulating expected or desired future changes under novel circumstances remains a substantial challenge. Because comparable alternative findings are rare, model results often go unchallenged and may be misinterpreted as predictions of how the future will develop rather than projections dependent upon underlying assumptions (Low and Schäfer, 2020). This could be particularly misleading in social systems such as those underpinning human land use, wherein no universal laws or predictable patterns exist to guide the representation of human behaviour in models. Modellers must therefore choose between a range of contested theoretical foundations, practical designs and evaluation strategies (Brown et al., 2016; Meyfroidt et al., 2018; Verburg et al., 2019).

In this complex context, the proper analysis and interpretation of model outputs are just as important as proper model design but have received less attention. Steps such as standardised model descriptions, open access to model code, robust calibration, evaluation and verification, benchmarking, and uncertainty and sensitivity analyses are all necessary to ensure that model results are interpreted appropriately (Baldos and Hertel, 2013; Sohl and Claggett, 2013). Currently, few if any of these steps are taken universally and rigorously in land use science (van Vliet et al., 2016; Brown et al., 2017; Saltelli et al., 2019). This study focuses on one in particular: the comparison or benchmarking of independent land use models against one another.

Comparison is especially important for land use models because a range of very different conceptual and technical approaches could be valid for simulating social-ecological dynamics (Filatova et al., 2013; Brown et al., 2016; Elsawah et al., 2020). In the absence of fair comparisons, it is impossible to objectively choose between these approaches or to identify the assumptions on which their outputs are most conditional. However, while comparisons of model outputs have been made (Lawrence et al., 2016; Prestele et al., 2016; Alexander et al., 2017), their ability to link particular outputs to particular methodological choices has been limited by the sheer number of differences between individual models.
Alexander et al. (2017), for instance, found that model type explained more variance in model results than did the climatic and socio-economic scenarios, but they were not able to determine exactly why.

These previous comparisons reveal a major challenge: the shortage of models that take distinct approaches in similar geographical and thematic areas, which would therefore allow for more controlled and informative comparison exercises. Most established models, especially those operating over large geographical extents, share a basic approach that optimises land use against economic, climatic and/or environmental objectives. Technical and geophysical constraints are often treated in detail, while social, institutional and ecological factors are rarely included (Brown et al., 2017; de Coninck et al., 2018; Obermeister, 2019). Large areas of system behaviour remain underexplored as a result (Brown et al., 2016; Huber et al., 2018; Meyfroidt et al., 2018), with the likely consequence that established findings have implicit biases and blind spots. These can be especially problematic for the simulation of future scenarios in which neglected aspects of land system change become prominent (Estoque et al., 2020) and can be partially if not fully revealed by structured comparison exercises.

In this article, we take advantage of the development of two conceptually distinct but practically equivalent models of the European land system to make a direct comparison between alternative modelling paradigms. We use the term "modelling paradigm" here to refer to a methodological approach that is based on a distinct theoretical description of the system in question: in this case "top-down" and "bottomup" approaches frequently identified as paradigms in the literature (Brown et al., 2016; Couclelis, 2002). These models, an Integrated Assessment Platform (IAP) and an agentbased model (ABM) share input data to run under the same internally consistent scenario combinations. The former is a constrained optimising economic-equilibrium model, and the latter is a stochastic behavioural model. We run both models for combinations of Representative Concentration Pathway (RCP) climate scenarios and Shared Socioeconomic Pathway (SSP) socio-economic scenarios (O'Neill et al., 2017), and we compare their projections of territorial and aggregate land use change and ecosystem service provision. We use this analysis to understand the effects and importance of the different assumptions contained in each model for simulated land use futures and draw general conclusions about the contributions of both approaches to understanding land system change.

\section{Methods}

This paper uses two contrasting models of the European land system: CRAFTY-EU (Brown et al., 2019b) and the IMPRESSIONS Integrated Assessment Platform (IAP) (Harrison et al., 2015, 2019). Both models cover all European 
Union member states except Croatia, and they also cover the UK, Norway and Switzerland. The IAP's simulated baseline land use map, land use productivities, scenario conditions and ecosystem service provision levels were used in CRAFTY-EU, making them uniquely equivalent examples of different modelling paradigms (Fig. 1). Both models were run for a subset of socio-economic and climatic scenario combinations, and their outputs were systematically compared, as described below.

\subsection{Model descriptions}

IMPRESSIONS IAP is an online model of European land system change that incorporates sub-models of urban development, water resources, flooding, coasts, agriculture, forests and biodiversity. Within this cross-sectoral modelling chain, rural land use is allocated within 30-year time slices according to a constrained optimisation algorithm that maintains equilibrium between the supply and demand for food and (as a secondary objective) timber by iterating agricultural commodity prices (cereals, oilseeds, vegetable protein, milk, meat, etc.) to promote agricultural expansion or contraction (Audsley et al., 2015). This model therefore aims to satisfy food demand (taking account of net imports) and does so optimally subject to constraints imposed by biophysical and socio-economic conditions. Calculations are carried out across overlapping geographically unstructured clusters of cells with similar biophysical conditions (based on soil and agroclimate), with profitability thresholds used to determine which land use and management intensity offer the greatest returns across each cluster. Land use proportions within each $10^{\prime} \times 10^{\prime}$ grid cell represent the aggregations of the optimal solutions for each (up to 40) associated cluster. At cell level, this aggregation therefore represents the (spatially weighted) optimised land use solution for each cluster containing the grid cell in question. The clustering recognises that different biophysical conditions (soil and agroclimate) differentially influence the suitability, productivity and profitability of different crops and different agricultural systems (arable, dairy, etc.), leading to heterogeneity in agricultural land use within a grid cell. The IAP runs from a present-day simulated baseline land use configuration to the mid-2080s under combined climatic and socio-economic scenarios. The IAP has been applied and evaluated in a large number of studies including sensitivity and uncertainty analyses (e.g. Brown et al., 2014a; Harrison et al., 2015, 2016, 2019; Kebede et al., 2015; Holman et al., 2017a, b; Fronzek et al., 2019). A full model description and the online model itself are available at http:// www.impressions-project.eu/show/IAP2_14855 (last access: 19 February 2021).

CRAFTY-EU is an application of the CRAFTY framework for agent-based modelling of land use change (Brown et al., 2019b; Murray-Rust et al., 2014) that covers the same extent as the IAP at the same $(10 \mathrm{arcmin})$ resolution. CRAFTY uses the concept of agent functional types (AFTs)
(Arneth et al., 2014) to simulate land use change over large geographical extents while capturing key behaviours of decision-making entities (agents) that include individual land managers, groups of land managers, and institutions or policy bodies (Holzhauer et al., 2019). Modelled land manager agents compete for land on the basis of their abilities to produce a range of ecosystem services that society is assumed to require. In CRAFTY-EU, these services include provisioning (food crops and meat, timber), regulating (carbon sequestration), cultural (recreation) and supporting services (habitat provision through landscape diversity). The abilities of agents to supply these services under given biophysical and socio-economic conditions are derived either from IAP model results (Fig. 1) or from basic assumptions linking land uses to service levels, as explained in Brown et al. (2019b). Satisfying demands for services brings economic and non-economic benefits to individual agents, with benefits quantified as functions of unsatisfied demand. In this case, these functions are linear and equivalent for all services, meaning that the benefit of production of each service increases equally per unit of unmet demand, providing a clear basis for model comparison. Economic benefit represents income from marketable goods and services, and noneconomic benefit represents a range of motivations from subsistence production to the maintenance of societal, cultural or personal values associated with particular services or land uses. Ecosystem service production levels are determined by the natural productivity of the land and the form and intensity of agents' land management. The outcome of the competitive process at each annual time step is determined by agent-level decision-making that is not constrained to generate the greatest benefit, and agents are parameterised here to continue with land uses that provide some return rather than abandon their land but to gradually adopt significantly more beneficial alternatives if available.

Importantly for this study, CRAFTY-EU is parameterised on the basis of the IAP, taking IAP outputs as exogenous conditions and replacing only the land allocation component to provide alternative land use projections under identical driving conditions (Fig. 1). CRAFTY-EU is initialised on the IAP's baseline map and is known to only diverge from that stable baseline "solution" as scenario conditions change (Brown et al., 2019b). Land use productivities, in terms of potential yields and ecosystem service provision levels of the simulated land use systems under the agronomic scenario conditions at cell scale, are also calculated from IAP outputs dependent on land use allocation, with the result that productivities are set to zero when the IAP determines production to be economically infeasible. For ecosystem services with economic values (meat, crops and timber), agents in CRAFTY therefore make production choices that conform to this basic level of economic feasibility while still being able to select a range of economically optimal or sub-optimal land uses. A full description of the model can be found in Brown et al. (2019b), and an online version with access to 


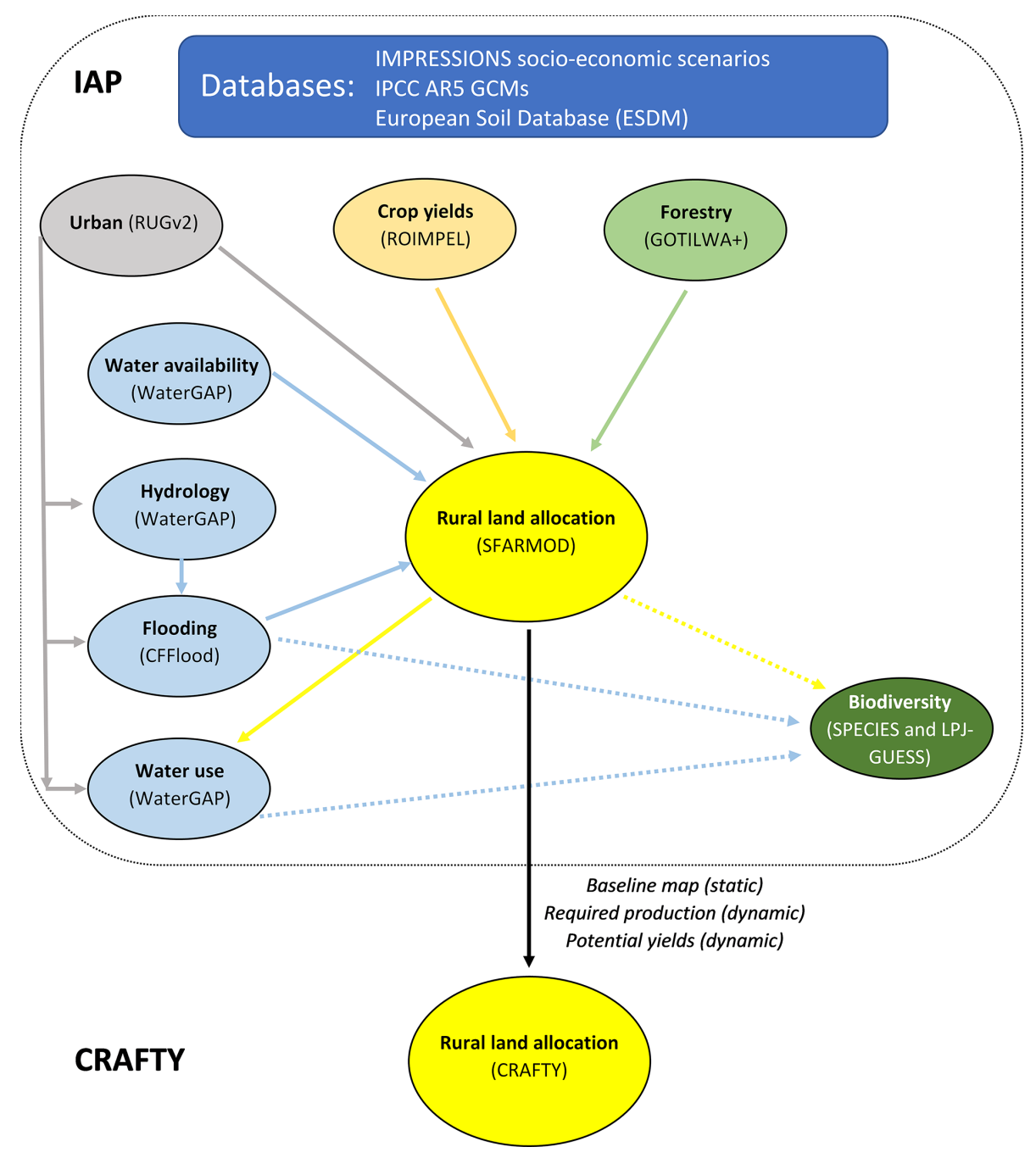

Figure 1. Simplified schema showing the structure of the IAP in terms of its component meta-models and its relationship to CRAFTY in this study. Results presented in this study are taken from the alternative land allocation models (yellow), and results from the biodiversity model are not used. The information transferred from the IAP to CRAFTY utilises all of the inputs to SFARMOD and describes initial and scenario-dependent conditions affecting agent decision-making in CRAFTY.

the full model code can be found at https://landchange.earth/ CRAFTY (last access: 19 February 2021).

\subsection{Climate and socio-economic scenarios}

Seven combinations of climatic and socio-economic scenarios were simulated based on the Representative Concentration Pathways (RCPs) and Shared Socioeconomic Pathways (SSPs) (O'Neill et al., 2017). The RCPs and SSPs were combined, taking account of internal consistency with their associated greenhouse gas emissions. RCP2.6 was combined with SSP1 and 4; RCP4.5 was combined with SSP1, 3 and 4, and RCP8.5 was combined with SSP3 and 5 (Table 1). The SSPs have been further developed for Europe through a stakeholder engagement process that included interpretation and quantification of key drivers of change in land-based sectors (Table 2a; Kok et al., 2019). For this study, RCPs were simulated in the IAP using outputs from two global-regional climate models (EC_Earth/RCA4 for RCP2.6 and HADGEM2-ES/RCA4 for RCP4.5 and 8.5 Table 2b; Harrison et al., 2019). Scenario outcomes are described for CRAFTY-EU in Brown et al. (2019b) and for the IAP in Harrison et al. (2019) and Papadimitriou et al. (2019). In addition to these established scenarios, one scenario combination (RCP4.5-SSP3) was simulated with additional variations in model parameterisations. This scenario was chosen as producing particularly divergent results between the two models, and parameter values were altered to constrain the differences in model responses to the scenario and therefore to reveal the roles of underlying assumptions in producing the observed divergence. Specifically, we increased imports in the IAP by $40 \%$ (to mimic an observed underproduction 
Table 1. Climatic and socio-economic scenario identities, summaries and main findings.

\begin{tabular}{|c|c|c|c|c|}
\hline & $\begin{array}{l}\text { SSP1 } \\
\text { Socio-economic conditions } \\
\text { gradually improve through } \\
\text { economic growth, stable } \\
\text { government, high social } \\
\text { cohesion and international } \\
\text { cooperation }\end{array}$ & $\begin{array}{l}\text { SSP3 } \\
\text { Social and economic } \\
\text { conditions worsen, with } \\
\text { limited and ineffective } \\
\text { political responses }\end{array}$ & $\begin{array}{l}\text { SSP4 } \\
\text { Large economic inequalities and } \\
\text { fluctuations develop, low social } \\
\text { cohesion, but high } \\
\text { technological investment and } \\
\text { environmental protection }\end{array}$ & $\begin{array}{l}\text { SSP5 } \\
\text { Emphasis on social and } \\
\text { economic development, } \\
\text { fossil fuel exploitation, } \\
\text { and technology }\end{array}$ \\
\hline $\begin{array}{l}\text { RCP2.6 } \\
\text { Very low } \\
\text { climate } \\
\text { change }\end{array}$ & $\begin{array}{l}\text { IAP simulates more } \\
\text { intensive and pastoral } \\
\text { agriculture and very } \\
\text { little forest. } \\
\text { CRAFTY increases } \\
\text { forest at the expense } \\
\text { agriculture. Undersupply } \\
\text { of timber } \\
\text { (especially in the } \\
\text { IAP) and undersupply } \\
\text { of food (only } \\
\text { in CRAFTY). }\end{array}$ & & $\begin{array}{l}\text { Widespread agricultural } \\
\text { extensification and } \\
\text { abandonment in the IAP } \\
\text { and more forestry, but } \\
\text { with undersupply of } \\
\text { timber (agriculture shifts } \\
\text { to optimal areas). More } \\
\text { intensive agriculture in } \\
\text { CRAFTY, but with undersupply } \\
\text { of food } \\
\text { (agriculture persists in } \\
\text { less optimal areas). }\end{array}$ & \\
\hline $\begin{array}{l}\text { RCP4.5 } \\
\text { Intermediate } \\
\text { climate } \\
\text { change }\end{array}$ & $\begin{array}{l}\text { Small differences, } \\
\text { with the IAP having a } \\
\text { slight shift towards } \\
\text { pastoral and very } \\
\text { extensive agriculture, } \\
\text { with less forest. }\end{array}$ & $\begin{array}{l}\text { Limited change in } \\
\text { the IAP but dramatic } \\
\text { loss of intensive } \\
\text { management in } \\
\text { CRAFTY, along with } \\
\text { fragmentation, } \\
\text { temporal dynamism } \\
\text { and supply shortfalls. }\end{array}$ & $\begin{array}{l}\text { Widespread agricultural } \\
\text { abandonment in the IAP. } \\
\text { CRAFTY supply levels } \\
\text { exceed demand. }\end{array}$ & \\
\hline $\begin{array}{l}\text { RCP8.5 } \\
\text { High climate } \\
\text { change }\end{array}$ & & $\begin{array}{l}\text { Limited change in } \\
\text { both models, with } \\
\text { more extensification, } \\
\text { forest and } \\
\text { multifunctional } \\
\text { production in } \\
\text { CRAFTY. }\end{array}$ & & $\begin{array}{l}\text { Widespread } \\
\text { agricultural } \\
\text { extensification and } \\
\text { abandonment in the } \\
\text { IAP. Limited } \\
\text { change in } \\
\text { CRAFTY, with } \\
\text { supply levels } \\
\text { exceeding demand. }\end{array}$ \\
\hline
\end{tabular}

of food in CRAFTY) and increased the value of food production in CRAFTY by 10 times (to compensate for reductions in supporting capital levels responsible for the underproduction of food).

\subsection{Conceptual framework}

The model comparison presented here is motivated by the hypothesis that the nature of simulated land use allocation is one dominant source of uncertainty in land use modelling, as opposed to uncertainty in crop yields, biophysical conditions or other land system characteristics. The selected models therefore allow us to keep the latter factors common and explore how different factors that influence land use allocation, such as profitability, non-economic motivations, demand levels and socio-economic conditions, affect model outcomes.
This is possible because the models used share much of their information and design features but adopt distinct paradigms for modelling the process of land allocation itself (Fig. 1, Table 3).

The IAP and CRAFTY-EU belong to distinct paradigms in the sense that the IAP is an example of a top-down model that simulates change at the system level - in this case through an assumption of constrained economic optimisation - while CRAFTY is an example of a bottom-up model that simulates change at the level of individual decision makers - in this case through an assumption of behavioural choices made at the level of local land systems (Brown et al., 2016; Couclelis, 2002). These paradigms usually have different uses and justifications: the (dominant) top-down approach is computationally efficient, tractable and more in line with economic theory, although it is rarely justified as an accurate repre- 
Table 2. (a) Details of the socio-economic scenarios (Shared Socioeconomic Pathways, SSPs) as simulated by the IAP. Values are shown for the 2080s time slice. Table adapted from Harrison et al. (2019). (b) Details of the climate scenarios used in both models. RCP denotes Representative Concentration Pathway. GCM: general circulation model, RCM: regional climate model. The change in temperature $(\Delta T)$ and change in precipitation $(\Delta \mathrm{Pr})$ are relative to $1961-1990$, and they affect productivities as simulated by meta-models in the IAP, which are then fed into the alternative land use models (Fig. 1). Further details are available in Harrison et al. (2019).

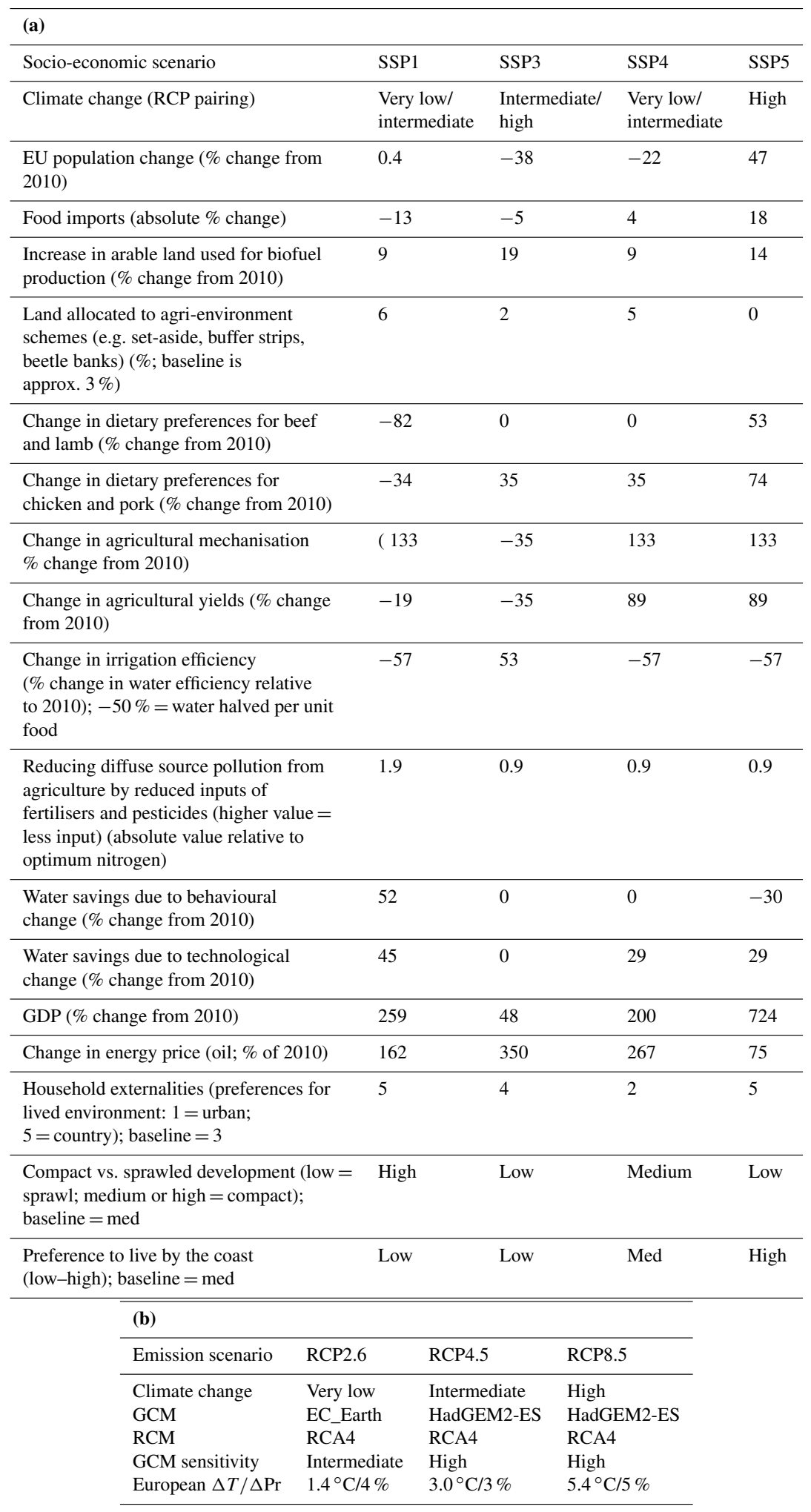


Table 3. Summary comparison of the two models used in this study across a range of characteristics, many of which stem from the distinct modelling paradigms used. Further details are provided in the text and the references cited therein.

\begin{tabular}{|c|c|c|c|}
\hline & IAP & CRAFTY-EU & Key differences \\
\hline $\begin{array}{l}\text { Modelling } \\
\text { paradigm }\end{array}$ & $\begin{array}{l}\text { Top-down model that } \\
\text { represents land use change } \\
\text { as a single systemic } \\
\text { response to drivers }\end{array}$ & $\begin{array}{l}\text { Bottom-up model that represents } \\
\text { land use change as emergent from } \\
\text { responses of multiple } \\
\text { entities within the system }\end{array}$ & $\begin{array}{l}\text { Entirely distinct } \\
\text { conceptualisation of } \\
\text { land use change within } \\
\text { shared reductionist } \\
\text { (modelling) approach }\end{array}$ \\
\hline $\begin{array}{l}\text { Theoretical } \\
\text { basis }\end{array}$ & $\begin{array}{l}\text { Consistent with positivist } \\
\text { and classical economic } \\
\text { theories of system-level } \\
\text { dynamic equilibrium } \\
\text { under exogenous pressures } \\
\text { (Brown et al., 2016) }\end{array}$ & $\begin{array}{l}\text { Consistent with methodological } \\
\text { individualism and subjective } \\
\text { expected utility theory of decision- } \\
\text { making given uncertainty and non- } \\
\text { economic motivations (Murray- } \\
\text { Rust et al., 2014; Brown et al., } \\
\text { 2016) }\end{array}$ & $\begin{array}{l}\text { Neither model explicitly } \\
\text { theory-driven but both are } \\
\text { consistent with opposing } \\
\text { theoretical movements }\end{array}$ \\
\hline $\begin{array}{l}\text { Land } \\
\text { allocation }\end{array}$ & $\begin{array}{l}\text { Optimisation to satisfy } \\
\text { food demand, subject to } \\
\text { constraints imposed by } \\
\text { biophysical and socio- } \\
\text { economic conditions }\end{array}$ & $\begin{array}{l}\text { Individual agent decisions based } \\
\text { on competition to satisfy demands } \\
\text { for ecosystem services }\end{array}$ & $\begin{array}{l}\text { Land allocation is } \\
\text { imposed in the IAP but } \\
\text { emergent in CRAFTY } \\
\text { and therefore more } \\
\text { variable }\end{array}$ \\
\hline $\begin{array}{l}\text { Variables } \\
\text { considered } \\
\text { (inputs) }\end{array}$ & Defined in Table 2 & $\begin{array}{l}\text { Potential and realised ES provision } \\
\text { levels (derived from the IAP and } \\
\text { dependent on the variables in Table 2) } \\
\text { and agent abilities to produce } \\
\text { ecosystem services, sensitivities to } \\
\text { capital levels, willingness, and } \\
\text { time-dependent probability of } \\
\text { abandoning their cells or } \\
\text { relinquishing to other land uses } \\
\text { when at a competitive } \\
\text { disadvantage, and abilities to } \\
\text { search for new cells to take over. }\end{array}$ & $\begin{array}{l}\text { Most inputs are shared } \\
\text { directly or indirectly, } \\
\text { although the IAP more } \\
\text { explicitly includes } \\
\text { biophysical conditions } \\
\text { and CRAFTY human } \\
\text { behaviour }\end{array}$ \\
\hline
\end{tabular}

\begin{tabular}{lll}
\hline $\begin{array}{l}\text { Mathematical } \\
\text { characteristics }\end{array}$ & $\begin{array}{l}\text { Produces single, optimal } \\
\text { results (subject to } \\
\text { constraints) at each } \\
\text { time slice }\end{array}$ & $\begin{array}{l}\text { Stochastic and path-dependent; } \\
\text { produces sub-optimal and variable } \\
\text { results }\end{array}$ \\
\end{tabular}

The IAP is more mathematically constrained, but complexity of "option space" makes results of both models difficult to anticipate

\begin{tabular}{|c|c|c|c|}
\hline Evaluation & $\begin{array}{l}\text { Extensively evaluated, } \\
\text { including uncertainty } \\
\text { analyses and comparison } \\
\text { to independent data and } \\
\text { other models (e.g. Brown } \\
\text { et al., 2014; Harrison et al., } \\
\text { 2015, 2016, 2019; Kebede } \\
\text { et al., 2015; Holman et al., } \\
\text { 2017a, b; Fronzek et al., } \\
\text { 2019) }\end{array}$ & $\begin{array}{l}\text { Extensively evaluated, including } \\
\text { uncertainty analyses and } \\
\text { comparison to independent data } \\
\text { and other models (Alexander et al., } \\
\text { 2017; Brown et al., 2014b, 2018b; } \\
\text { Holzhauer et al., 2019; Seo } \\
\text { et al., 2018) }\end{array}$ & $\begin{array}{l}\text { No significant } \\
\text { difference, noting that } \\
\text { neither model targets } \\
\text { accurate reproduction of } \\
\text { observed changes }\end{array}$ \\
\hline $\begin{array}{l}\text { Uncertainty } \\
\text { and } \\
\text { sensitivity }\end{array}$ & $\begin{array}{l}\text { Well-understood, with } \\
\text { land use outcomes most } \\
\text { sensitive to temperature, } \\
\text { precipitation, yields and } \\
\text { import levels (Kebede et } \\
\text { al., 2015) }\end{array}$ & $\begin{array}{l}\text { Well-understood, with land use } \\
\text { outcomes most sensitive to yields } \\
\text { (including climate effects), import } \\
\text { levels and (to lesser extent) agent } \\
\text { behaviour (Brown et al., 2018b) }\end{array}$ & $\begin{array}{l}\text { CRAFTY has } \\
\text { sensitivities to } \\
\text { behavioural parameters } \\
\text { not present in the IAP }\end{array}$ \\
\hline
\end{tabular}


Table 3. Continued.

\begin{tabular}{llll}
\hline & IAP & CRAFTY-EU & Key differences \\
\hline $\begin{array}{l}\text { Spatial } \\
\text { resolution }\end{array}$ & $\begin{array}{l}\text { 10 arcmin (approx. 16 km } \\
\text { in Europe), with up to } \\
40 \text { forms of land use and } \\
\text { management proportionally } \\
\text { distributed within each } \\
\text { cell }\end{array}$ & $\begin{array}{l}\text { 10 arcmin (approx. 16 km in Europe), } \\
\text { with continuous variation in } \\
\text { characteristics within 17 forms of } \\
\text { land use and management }\end{array}$ & $\begin{array}{l}\text { Identical resolution for } \\
\text { defined classes, but } \\
\text { different forms and } \\
\text { extents of variation } \\
\text { within those classes }\end{array}$ \\
\hline $\begin{array}{l}\text { Temporal } \\
\text { resolution }\end{array}$ & $\begin{array}{l}\text { Time slices: baseline, } \\
\text { 2020s, 2050s, 2080s }\end{array}$ & Annual 2016-2086 & CRAFTY has higher \\
\hline $\begin{array}{l}\text { Principal } \\
\text { uses }\end{array}$ & $\begin{array}{l}\text { Research, education, } \\
\text { capacity building (students } \\
\text { and stakeholders) }\end{array}$ & Research, education & temporal resolution \\
\hline
\end{tabular}

sentation of how land use decisions are made in practice (in fact the evidence tends to contradict it; e.g. Chouinard et al., 2008; Schwarze et al., 2014; Appel and Balmann, 2019). The bottom-up approach, in contrast, is more exploratory and often criticised for producing uncertain results, but it explicitly attempts to achieve greater process accuracy (Brown et al., 2016).

Neither of these models is intended to accurately predict real-world land use change but to project land system dynamics on the basis of complex and integrated processes founded on a small number of key transparent assumptions. This comparison is therefore intended first and foremost to explore the reasons for simulated land use changes, and does not speak directly to observed land use changes. Nevertheless, both models have been extensively used and evaluated, and both respond stably and predictably to driving conditions (Brown et al., 2014a, 2018b, 2019b; Harrison et al., 2016, 2019; Holman et al., 2017b). Both also have similar uses, being intended to support academic research, education and, to some extent, capacity building with stakeholders to increase understanding of the importance of socio-economic and climatic changes, systemic inter-relationships in the land system, and geographic regions that may be particularly vulnerable or resilient to change. As a result, the comparison does not consider model purpose or the suitability of either model for direct policy support, prediction or other unintended uses.

Further, some of the effects of the different land allocation mechanisms contained in these models are apparent a priori. As a bottom-up agent-based model, CRAFTY is less constrained than the IAP, with multiple outcomes being possible from a given set of input conditions. At the same time, land use decisions are subject to behavioural inertia in CRAFTY, with agents unwilling to change existing land uses and motivated by non-economic factors that can counteract price signals. The IAP will always identify the optimal result subject to economic drivers and modelled constraints, and it does so without reference to the previously simulated time point (i.e. is not path-dependent). It is therefore expected that the IAP responds more to smaller changes in conditions than does CRAFTY and that the models are likely to diverge as time goes on and as the magnitude of changes increases.

\subsection{Comparison}

In this study, both models are run until the mid-2080s (defined as a 30-year time slice in the IAP and the year 2086 in CRAFTY-EU). Both use a spatial grid of resolution $10 \operatorname{arcmin} \times 10$ arcmin (approximately $16 \mathrm{~km} \times 16 \mathrm{~km}$ in Europe), but simulated land classes differ between the two models (as described in Brown et al., 2019b) and are standardised here as described in Table 4 to focus on major comparable forms of agricultural and forestry management. These aggregate land use classes are not homogeneous or uniform across the simulations as they allow for a range of management forms within them. We therefore also compare ecosystem service production levels, which account for actual forms of management simulated in each cell. Urban land use is not compared as its locations are shared by both models.

The comparison of these land use classes was made at two spatial resolutions: across the whole of the modelled domain (without reference to spatial configurations) and across 323 Nomenclature of Territorial Units for Statistics (NUTS2) regions. NUTS2 resolution was chosen for the spatially explicit comparison instead of the original $10^{\prime}$ model resolution to limit the impact of relatively uninformative differences in the allocation of individual cells and to focus instead on systematic differences in model responses to the simulated scenarios. This choice also reflects the fact that neither model is intended to predict cell-level outcomes but to provide illustrative realisations of scenario outcomes, with the cell-level results of CRAFTY-EU differing between individual runs because the model is stochastic and path-dependent. At NUTS2 level, only differences between the models affecting at least $5 \%$ of the relevant cells were included in the analysis. In the following sections (the Results and Discussion sections), CRAFTY-EU is referred to simply as CRAFTY for brevity. 
Table 4. Land use classes used in the comparison and their composition. Derivations from the full range of CRAFTY and IAP classes are given in Table A1.

\begin{tabular}{ll}
\hline Land use classes for comparison & Explanation \\
\hline Intensive agriculture & $\begin{array}{l}\text { Intensive forms of agriculture primarily dedicated to crop production but including } \\
\text { some grassland }\end{array}$ \\
\hline Extensive agriculture & Extensive forms of arable and pastoral agriculture \\
\hline Pastoral agriculture & Dedicated and primarily intensive pastoral agriculture \\
\hline Very extensive management & $\begin{array}{l}\text { Management for any service that is of the lowest intensity and leaves land in a } \\
\text { nearly natural state }\end{array}$ \\
\hline Forestry & Active management for timber extraction and other forest services \\
\hline Other/no management & $\begin{array}{l}\text { Land that is not actively managed for agriculture or forestry, but which can have a } \\
\text { range of natural or human-impacted land cover }\end{array}$ \\
\hline
\end{tabular}

The presentation of the results below is structured to reveal the effects of the paradigmatic differences between the models (and not to assess the models' shared characteristics). First, we compare outputs from each scenario at EU scale to identify the principal differences that arise in the simulations. Because the scenarios relate to the modelling paradigms in different ways (e.g. allowing for stronger or weaker economic signals), this allows us to link the results to particular modelling choices. We then compare results at NUTS2 level to identify relatively minor or hidden differences before experimenting with forced convergence to test the role of particular parameters and assumptions in each model.

\section{Results}

\subsection{EU-level aggregate comparison}

The responses of the two models to scenario conditions are notably different in most cases (Figs. 2 and 3, Table 1), albeit within similar broad limits (Fig. 2). The greatest similarities in terms of aggregate land use classes occur in the SSP1 simulations, in which both models produce land systems that remain similar to the baseline, with large areas of intensive agriculture and small areas of land not managed for agriculture or forestry. The IAP results include more dedicated pastoral land and the CRAFTY results more forestry. In all simulations with very low climate change (RCP2.6), CRAFTY produces an undersupply of food and both models produce an undersupply of timber; these shortfalls are reduced under intermediate climate change (RCP4.5), whereby productivity is slightly higher (Fig. 3). CRAFTY produces smaller imbalances between food and timber supplies due to its equivalent valuation of all modelled services.

In other scenarios, the IAP responds most strongly to SSP4 and 5, while CRAFTY responds most strongly to SSP3. At aggregate level, CRAFTY produces similar results in the SSP4 and 5 simulations as in SSP1 (Fig. 2), though with generally less intensive agriculture and higher supply levels (even exceeding demand in the higher climatic productivities of RCP4.5 and 8.5) (Fig. 3a). In contrast, the IAP projects a dramatic move away from intensive agriculture in SSP4 and 5 as a consequence of greatly increased productivity requiring a smaller agricultural area to meet demand. This loss of agricultural management in previously intensively managed areas is far more pronounced in the IAP than in CRAFTY, wherein the wider range of valued ecosystem services supports more management and, in some cases, oversupply of services (Fig. 3). The extent of agricultural abandonment is greatest in the IAP under intermediate climate change (RCP4.5), whereby increased yields in some areas reduce the relative competitiveness of agricultural land in less productive areas. Differences in the simulated extent of intensive arable management are equivalent to $25 \%$ of the EU land area in some cases.

SSP3 produces considerably smaller responses in the IAP, with some areas of all land use types going out of management and with far larger areas of the intensive agriculture class remaining than in SSP4. CRAFTY outcomes for SSP3 are highly dependent on the climate scenario, with RCP4.5 producing the strongest response, most notably in terms of a large shortfall in the supply of crops (of up to $56 \%$ of demand; Fig. 3a). In this case, widespread extensification of land use occurs, with little intensive agriculture remaining by the end of the simulation and a slight increase in land going out of agricultural or forestry management. In RCP8.5 these changes are less pronounced, with only small changes from intensive agriculture to extensive and forestry management. These changes occur because SSP3 includes deteriorating inherent agricultural productivity and also substantial declines in capital values that support land management (particularly financial, human and manufactured capitals). In CRAFTY, these simultaneous changes make it difficult for agents to maintain intensive management against competition from extensive and less capital-dependent forms of man- 


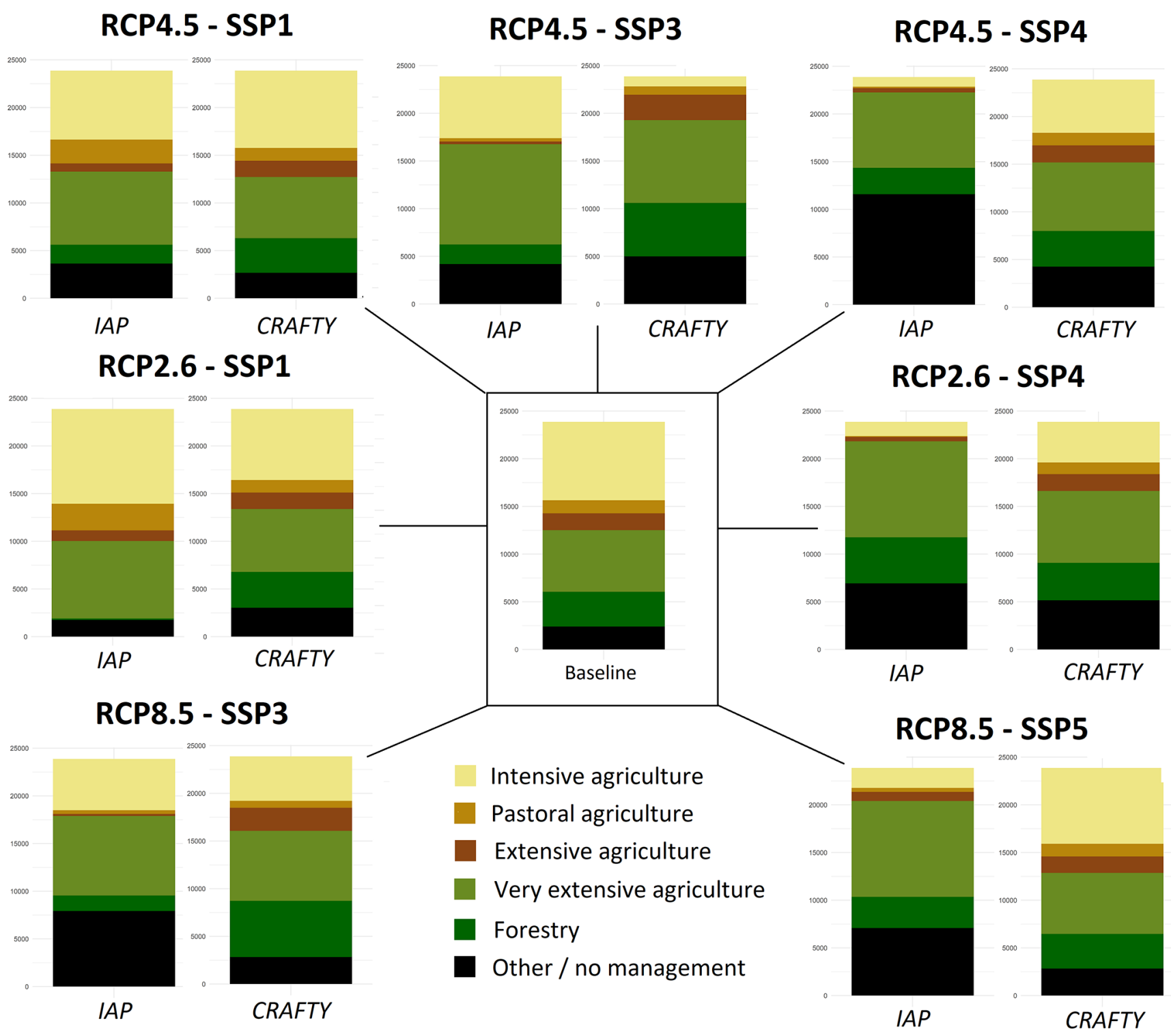

Figure 2. Simulated land use classes for each scenario in each model in the mid-2080s. Bars show the number of cells occupied by each class out of the total number of 23871 cells ( $y$ axes). Climate scenarios (RCPs) are arranged in rows. The baseline is identical in both models and is therefore only shown once.

agement. The increased yields in some parts of Europe produced by climate change in RCP 8.5 make this scenario more conducive to the maintenance of intensive management.

The models also respond very differently to the SSP5 scenario (paired only with RCP8.5). In the IAP, large areas switch to extensive and other/no management classes, while there is very little overall change in CRAFTY. The differences between the models' responses are mainly due to the higher yields and improved technological conditions in SSP5 making large areas of intensive agriculture surplus to requirements. These surplus areas are no longer intensively managed for agriculture in the IAP by the 2080s, but they are in CRAFTY (resulting in an oversupply of food) because they provide other services and because of the gradual decisionmaking of agents that spreads abandonment decisions over multiple time steps.

Together, these scenario results show that the IAP responds most strongly to scenarios with conditions in which agricultural productivity increases and which therefore lead to reduced need for agricultural land and, in this model, extensification and agricultural abandonment (which occurs over larger extents in the IAP than in CRAFTY). CRAFTY responds less strongly to such conditions because agents have a (parameterizable) unwillingness to change or abandon their land use in the absence of a more viable alternative and because a wider range of services produces returns for those 


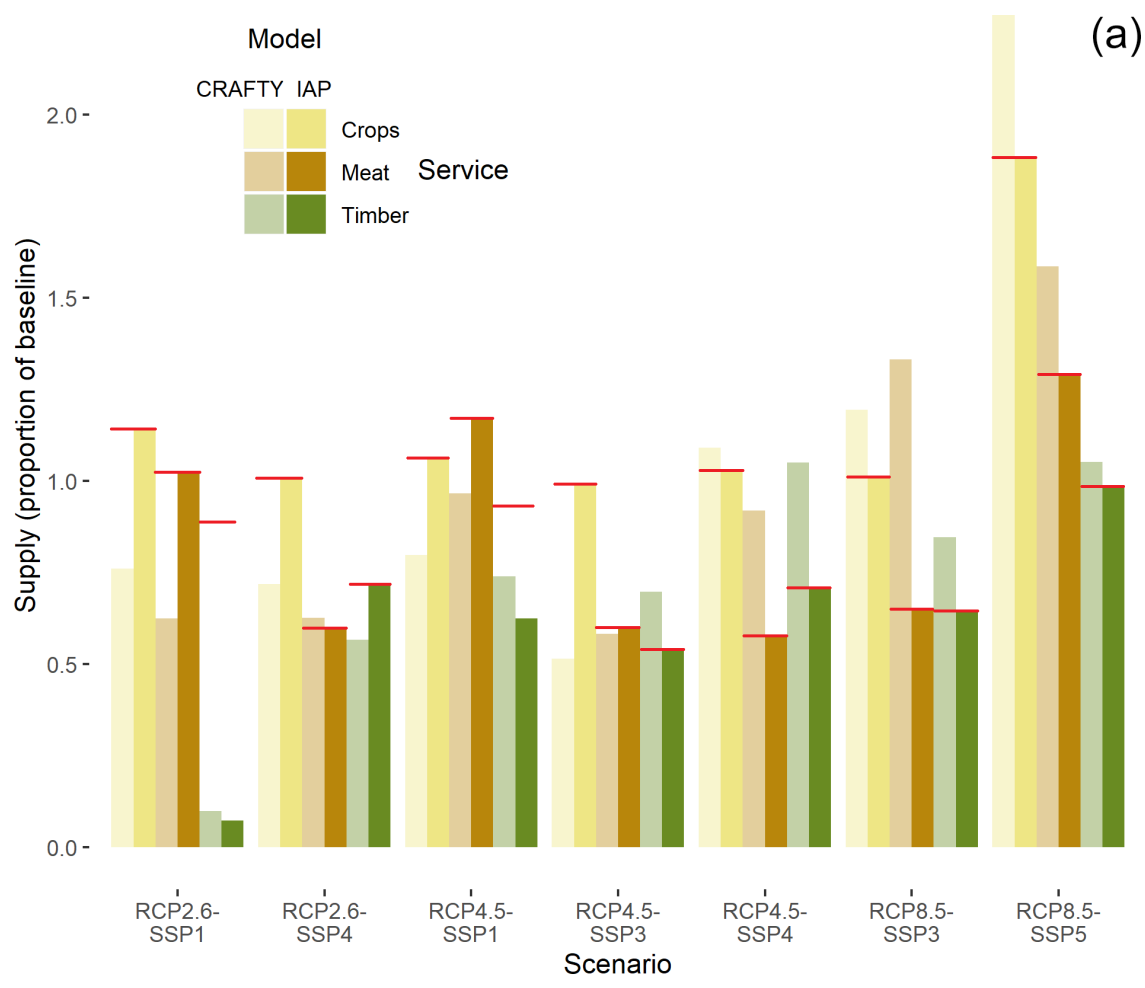

$4-$

(b)

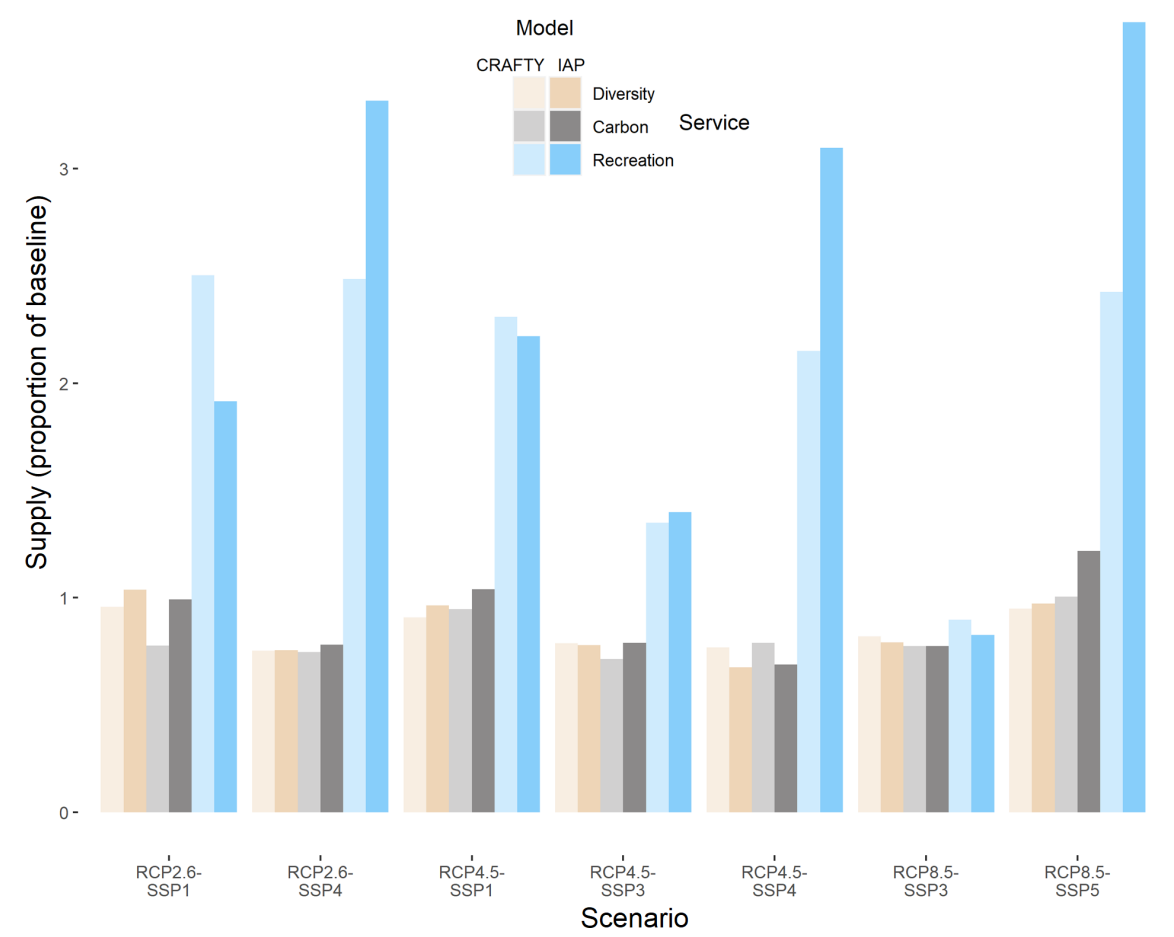

Figure 3. (a) Supply levels of services for which both models attempt to satisfy demand. Supply levels are shown for each scenario, and demand levels (derived from the IAP) are indicated by a red line for each service. IAP supplies are unequal to demand levels only where the IAP reports an underproduction of a particular service (in these results, timber in SSP1 simulations). A supply value of 1.0 ( $y$ axis) is equal to baseline supply. (b) Supply levels of services for which only CRAFTY attempts to satisfy demands (while the IAP does not). IAP supply levels here are calculated using CRAFTY production functions and then set as demands for CRAFTY. Demand levels are therefore equal to IAP supply by default and are not indicated by a line as in (a). A supply value of 1.0 ( $y$ axis) is equal to baseline supply. 


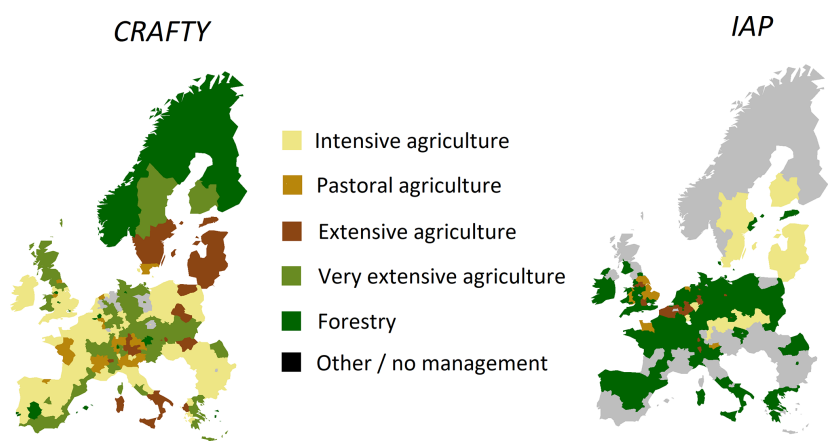

Figure 4. Territorial differences between the models' results across all scenarios at NUTS2 level. Colours identify the most overrepresented land use type in each region in the CRAFTY and IAP results relative to the result of the other model (i.e. the land use with the biggest difference in occurrence in that region). Grey is shown where no land use type has an over-representation of more than $5 \%$ of the region's cells. Scenario-specific results are shown in Fig. B1.

agents. Conversely, CRAFTY responds most strongly to scenarios in which conditions affecting agricultural productivity worsen because agents rely more strongly on a range of climatic and socio-economic conditions. Many of these conditions deteriorate in SSP3, making intensive agriculture less competitive than extensive agriculture or other multifunctional land uses and causing intensive agents to be easily replaced (competition is a more rapid process than abandonment in the CRAFTY parameterisation used here).

\subsection{Territorial comparison}

Within the aggregate differences between model results there are some consistent spatial and territorial patterns (Fig. 4). Across scenarios, the IAP often places more pastoral and very extensive land use classes in western Europe in particular, while CRAFTY often has more intensive agriculture at mid-latitudes and forest in eastern and northern areas (Figs. 4 and B1). These differences are very scenario-dependent, however, and as with the aggregate summaries above, the spatial patterns produced by one model in SSP3 resemble those produced by the other model in SSP4. In SSP4, the IAP projects substantially more very extensive agricultural management and forest management than CRAFTY, while the nearly inverse is true for SSP3 (reflecting implicit assumptions that overproduction is not penalised in CRAFTY and that intensive agriculture retains an efficiency advantage over extensive in the IAP). CRAFTY also produces a great deal more forest management in RCP2.6-SSP1, with intensive arable agriculture dominating only in the most productive parts of France, Germany and the UK. SSP1 is also the scenario in which the IAP produces the most concentrated areas of intensive pastoral agriculture, particularly in Ireland, the UK and France.
Notwithstanding the smaller-scale fragmentation of land uses in CRAFTY (see below), these results show that at this aggregate level, CRAFTY has a tendency (except in SSP3) to concentrate intensive agriculture at mid-latitudes, extensive agriculture in the southern Baltic states and very extensive land uses at the European latitudinal extremes. Forestry is distributed in the western UK and central-eastern states in particular. The IAP results are less consistent but show a tendency to produce pastoral agriculture in the west and forestry more widely. Many of these differences may reflect the valuation of a wider range of services in CRAFTY, leading to a concentration of intensive management in the most productive areas where it can maintain relative competitiveness. As above, they also reflect the differences in the conditions to which the models respond, with the IAP particularly sensitive to changes in demand that do not have spatial manifestations and CRAFTY more sensitive to capitals that are maximised in climatically suitable but also politically stable and affluent countries.

\subsection{Convergence experiment}

The scenario combination RCP4.5-SSP3 was chosen as having particularly different results from the two models, so it was used to examine the potential for convergence in model settings and results. In this scenario, CRAFTY produces a highly fragmented land system with areas of abandoned or extensively managed land scattered throughout Europe and a substantial shortfall in food production. The IAP, in contrast, produces large contiguous agricultural areas with far more intensive management (albeit of greatly reduced productivity) and less forestry, satisfying food demands. To control for the main differences in scenario conditions in each model, we increased food imports in the IAP to produce lower production levels in the EU, as observed in the CRAFTY result, and we increased food prices in CRAFTY to produce greater support for intensive agriculture, as observed in the IAP result. In the absence of these major differences, any remaining divergence in model outputs could be attributed to other factors.

In terms of aggregate land system composition, the changes in the IAP (an increase of $40 \%$ in food imports) did not lead to a result approaching the original CRAFTY results (Fig. 5). While the extent of intensive agricultural management did decrease, this led to widespread agricultural abandonment rather than additional extensive or forestry management (demand which was already satisfied), with remaining food production being even more concentrated in certain intensively managed parts of Europe (particularly the east). Large parts of southern and northern Europe fell out of agricultural management, with other regions and countries being managed only for forestry. Other results (above) suggest that the IAP would have more closely resembled the CRAFTY result had there been an explicit driver for extensification rather than simply an effective decrease in demand levels. 


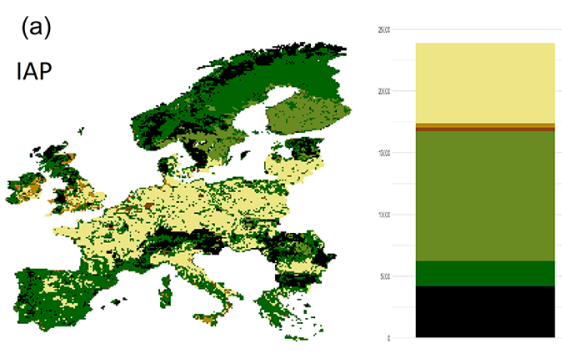

(c)
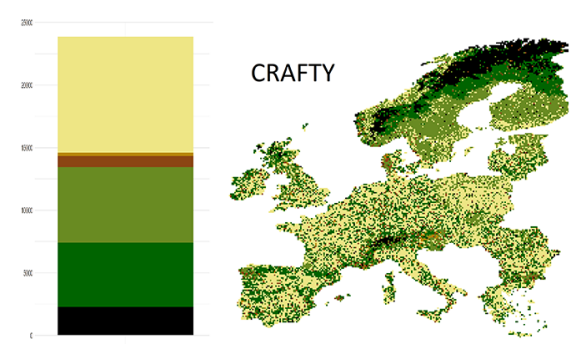

$40 \%$ increase in imports

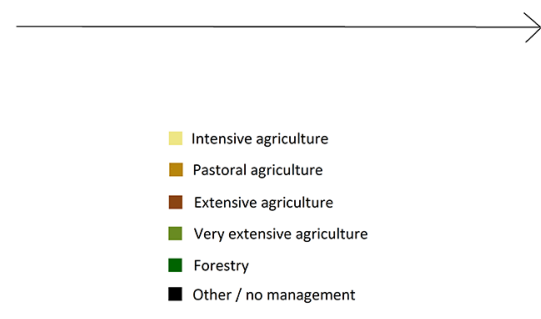

(b) IAP
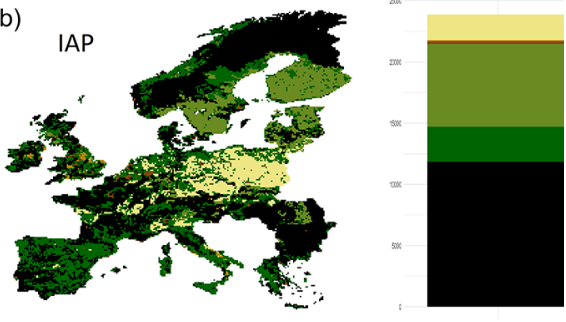

(d)
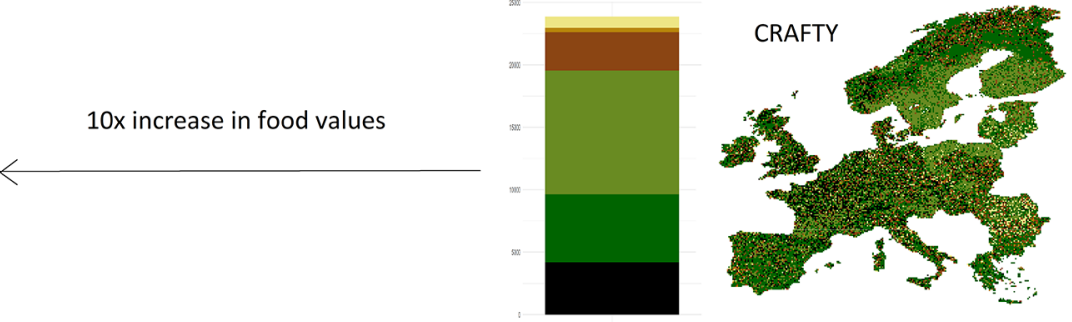

Figure 5. Cell-level and EU-level results for the RCP4.5-SSP3 scenario with and without alternative parameterisations designed to introduce analogous driving conditions to each model in turn. The IAP experiment is shown in (a, b), and the CRAFTY experiment is at the bottom. The original IAP result (a) moves towards the original CRAFTY result (d) with a $40 \%$ increase in imports allowing less production of food within Europe, resulting in widespread land abandonment in the new IAP result (b). The original CRAFTY result (bottom right) moves towards the original IAP result (a) with a 10-fold increase in food prices used to stimulate production, resulting in far more intensive agriculture in the new CRAFTY result (c). In neither case do the new results reproduce the original extremes.

From the more extensively managed and fragmented initial result produced by CRAFTY, a 10-fold increase in food prices did come closer to the initial IAP result, although there was more intensive agriculture and less land under other or no management. The distribution of land uses was strikingly different, however. Unmanaged land mainly occurred in the same areas, and concentrations of forestry overlapped to some extent, but the agricultural land in the CRAFTY result remained highly fragmented across much of Europe. In this case, CRAFTY produced sufficient food to satisfy demand.

\section{Discussion}

Understanding the contributions of different modelling paradigms to land use projections is important for two main reasons. The first reason is that almost all large- to globalscale land system models share a single paradigm (economic optimisation of land uses), raising the risk of biases in model results and resultant unrecognised knowledge gaps (e.g. Verburg et al., 2019; Elsawah et al., 2020; Müller et al., 2020). The second reason is that different paradigms are known to produce very different outcomes but for reasons that remain unclear (Alexander et al., 2017; Prestele et al., 2016). The focused comparison presented here is therefore intended to identify and explain key differences between models repre- senting major distinct paradigms. While conclusions are inevitably limited by the breadth of the comparison, in particular by the many characteristics that are shared between the selected models (Table 3), our results do reveal large and consistent differences that emerge from the different ways in which those models represent land system change.

The consequences of top-down and bottom-up perspectives are apparent in the form, extent, rate and patterns of land use change as the models respond to scenario conditions. The IAP's consistent profitability thresholds within a deterministic optimising framework respond strongly to increasing yields or decreasing demands when the model produces widespread agricultural abandonment outside the most productive land. Conversely, CRAFTY's heterogeneous competition process within a stochastic agent-based framework responds more strongly to decreases in productivity when the model produces extensification and expansion of agriculture. This difference is also apparent in our convergence experiment, in which increased imports in the IAP lead to reduced agricultural area, ensuring efficient production where competitiveness is highest rather than the extensification that CRAFTY produces. Increasing food prices in CRAFTY did generate aggregate land use proportions similar to those of the IAP, albeit with largely distinct spatial distributions, suggesting that agents become more "optimal" in behaviour when greater competitive advantages are available. 
To some extent these differences are traceable to the underlying mathematical structures of the models, with the IAP identifying any change in optimal configurations and CRAFTY maintaining existing and multifunctional land uses where possible. But the results are also subject to model sensitivity and uncertainty. Previous analyses show that the IAP responds most strongly to changes in demand levels and climate-driven yields and that their effects outweigh those of socio-economic scenarios (Brown et al., 2014a; Kebede et al., 2015). CRAFTY has similar sensitivities complemented but not overwhelmed by simulated agent behaviour (Brown et al., 2018b, 2019b). Together these suggest that the effects and differences we find are robust and traceable to model design interacting primarily with climatic scenarios (RCPs) and with socio-economic scenarios (SSPs) to a lesser extent.

Particularly influential is the representation in CRAFTY of individual and societal desires for a range of ecosystem services, which means that extensive management practices that provide recreation, carbon sequestration or landscape diversity, for example, are adopted instead of land abandonment. This is not necessarily tied to the modelling paradigm; optimisation can in principle be performed across a range of criteria, potentially accounting for many more (economically valued) ecosystem services, although this remains conceptually and computationally challenging (Newland et al., 2018; Seppelt et al., 2013; Strauch et al., 2019). The non-optimising representation used in models such as CRAFTY is closer to the reality of how land use actually changes (Appel and Balmann, 2019; Schwarze et al., 2014) but still requires additional parameterisation and rigorous uncertainty analysis (Verburg et al., 2019). In either case, there is strong justification for including a wide range of ecosystem services, particularly those such as carbon sequestration that may gain distinct values in different future scenarios (Estoque et al., 2020; Kay et al., 2019).

One consequence of simulating the demand and supply of a range of ecosystem services is that the relative economic support available for food production becomes a key determinant of the balance of different land uses because agriculture, while still dominant in area, must compete with alternative management options. Models such as the IAP seek to maintain food supplies, even at the expense of other services such as timber production, while models such as CRAFTY allow supply levels to emerge from simulated decisions and are therefore capable of producing shortfalls. All the results of the models are affected by this basic assumption about whether equilibrium does or will exist in the food system and further by the extent of disequilibrium that is tolerated and the mechanism by which that extent is defined. For instance, food prices in CRAFTY can respond to shortfalls in production through a number of parametric functions, while the in the IAP prices are automatically adjusted within broad limits to ensure that demand and supply match. However, shortfalls in food production in CRAFTY do not lead to simulated hunger, societal unrest or migration, and food prices in the IAP may become unrealistically high in scenarios in which economic and social conditions are very challenging (Hamilton et al., 2020; Pedde et al., 2019). In both models, the simulation of the European land system as distinct from the rest of the world requires implicit but shared assumptions about conditions in other regions and their relationships to Europe. Alternative assumptions would inevitably lead to different outcomes and, perhaps, greater differences between the two models' results. As conceptual alternatives, therefore, neither of these necessarily captures the true dynamics of food prices and production levels, which remains a major challenge for land system modelling (Müller et al., 2020; Pedde et al., 2019).

Beyond differences at aggregate level, another notable feature of the results shown above is that CRAFTY produces far more small-scale heterogeneity in land use than does the IAP. This heterogeneity is particularly pronounced in CRAFTY's SSP3 simulations (Fig. 5) and reflects a basic modelling approach: the simulation of time-dependent decisions affecting individual cells, with agents parameterised here to abandon land only if it provides no returns and then only gradually. This effectively precludes the system-level optimisation practised by the IAP, which does not account for individual land use decisions. Individual-level heterogeneity is, inevitably, very difficult to parameterise precisely, although participatory techniques have some promise in this respect (Elsawah et al., 2015). Conversely, (constrained) optimising models like the IAP produce results that may not replicate observed rates or spatial structures of land use change (Brown et al., 2019a; Low and Schäfer, 2020; Turner et al., 2018), but they can introduce spatial dependencies as further constraints on optimisation in order to approximate spatially mediated social processes such as imitation (Brown et al., 2018a; Meiyappan et al., 2014). Bottom-up models in general tend to be less precisely specified, so they produce more variable results (or are more "skittish", as Couclelis, 2002, put it). They are also generally less often compared against observational (or other modelled) data, and while their flexibility makes fitting to data notably feasible in principle, their inherent tendency to produce variable results means that the production of any one particular outcome does not have the apparent significance that it does for a more constrained model. Both models used here have been compared against "observed" land use data to some extent, with an example application of CRAFTY compared and calibrated to MODIS land cover data (Seo et al., 2018) and the IAP (and hence, indirectly, CRAFTY) calibrated to match CORINE land cover and NUTS2 yields (Harrison et al., 2015).

Notwithstanding the gains to be made by better understanding the relative performance of different modelling paradigms, it is essential to recognise some hard limits. No land use model is intended or able to provide calibrated representations of all the mechanisms responsible for land use change, especially under imagined future conditions. Models of this kind are inevitably reductionist in nature and omit 
a large number of important factors and processes that occur in reality - particularly, in this case, those occurring at smaller spatial scales than are simulated here. Both alternatives must therefore be seen as providing realisations of assumptions that are useful in some ways but incorrect in others. Optimising models have the advantage of representing idealised conditions in that they maximise the achievement of modelled criteria, such as production levels, but do not necessarily reveal pathways by which those conditions can be reached in reality (Ligmann-Zielinska et al., 2008; Low and Schäfer, 2020). Process- or agent-based approaches, meanwhile, can allow exploration of the large behavioural uncertainties involved in the simulation of human systems and can be powerful tools for stakeholder engagement and understanding (Low and Schäfer, 2020; Millington et al., 2011), but they are unlikely to perform any better at predicting system outcomes than simpler, more tightly constrained models (Salganik et al., 2020). Indeed, their primary strength may be their ability to use theory (and therefore to allow a choice among theories) as a guide to processes and conditions that empirical data and optimising models do not cover (Gostoli and Silverman, 2020). Both types of models represent abstracted units, managers and characteristics of land, which do not exactly match real-world conditions as experienced and determined by actors in the system (e.g. productivities and profits used to drive the models are not the same as those available to real-world land managers).

Fundamentally, no single modelling paradigm is "correct", and future developments are likely to invalidate even those assumptions that appear safest at the present time. The greatest value of these two approaches may therefore lie in their ability to provide alternatives. This value is realised only in the (currently rare) cases when analogous models with similar driving conditions but different underlying assumptions, such as those used here, are available for comparison (Müller et al., 2014; Polhill and Gotts, 2009; Rosa et al., 2014). Further benefits can be drawn from combinations of the two modelling approaches, although this usually involves an artificial choice of systems or scales at which topdown optimisation and bottom-up emergence are assumed to occur (e.g. Castella and Verburg, 2007; Verburg and Overmars, 2009; Houet et al., 2014). In addition, the benefits of using each type of model can be maximised (and the differences between them potentially minimised) by flexible multicriteria optimisation on one hand and behavioural uncertainty analysis on the other (Brown et al., 2018b; Fonoberova et al., 2013; Ligmann-Zielinska et al., 2014; Newland et al., 2018). Nevertheless, substantial efforts to increase both the diversity and coherence of land system modelling are likely to be necessary if these important gains are to be made.

\section{Conclusions}

In taking two particular models as representative of major modelling paradigms we can only draw tentative conclusions about the consequences of those paradigms for model outputs. Nevertheless, we find large, consistent differences between the models that are robust to known model sensitivities and directly traceable to basic assumptions. In particular, we find that the "bottom-up" agent-based model produces more heterogenous, multifunctional land systems than the "top-down" model, as expected. We also find that the models respond most strongly to different scenario conditions, despite both being sensitive to climatic effects on yields and socio-economic effects on demand levels. In particular, the constrained optimisation of the top-down model is able to capitalise on increases in productivity by utilising the best land, while the agent-based model is limited by inertia and path dependency in simulated conditions. Conversely, reductions in productivity, including through socio-economic disruption, prompt widespread extensification of land management in the bottom-up model that is not replicated in the topdown model, as simulated agents diversify and rely on more varied or even non-economic benefits. Currently, these two modelling paradigms are far apart in their projections of future change, with highly divergent outcomes for European land use and food supplies. This suggests huge uncertainty about the role the land system can and will play in societal challenges such as climate change and biodiversity loss, especially if impacts of large-scale events such as pandemics and political disruption are considered. However, this comparison suggests that such divergence, and hence uncertainty, rests largely on a few key features, in particular the assumed extent of non-economic decision-making, the relative importance that society places on cultural and regulating ecosystem services compared to provisioning, and the likely rate of land use change, including abandonment and intensification, as outcomes of human decisions. Our findings show the importance of communicating these assumptions to model users but also of identifying better supported and more generally accepted positions that narrow the gap between the current extremes of dominant paradigms. 
Appendix A: Land use class composition

Ecosystem service production in CRAFTY is derived from that of the IAP, which uses a suite of meta-models to simulate production levels as described in Harrison et al. (2019), and is presented in detail in Brown et al. (2019b). CRAFTY-EU also shares a baseline map with the IAP, with the aggregated land use classes used here derived from CRAFTY's agent functional types (AFTs) and the IAP's land use classes as described in Table A1.

Table A1. The composition of the aggregated land use classes used here in terms of CRAFTY-EU's agent functional types (AFTs) and the IAP's land use categories. In any case in which the given IAP categories occupy more than $70 \%$ of a cell, that cell is allocated to the corresponding AFT in the baseline map of CRAFTY-EU, except in the case of the peri-urban AFT, for which the threshold (of urban area) is $40 \%$. The service production potentials of each AFT are calibrated to approximately match those within the IAP classes that constitute them so that given the same productivities in a cell, the same levels of services will be produced. Names are therefore assigned in both cases on the basis of dominant land uses and do not account for minor variations in land use and production within them.

\begin{tabular}{|c|c|c|}
\hline Agent functional type & IAP class & Aggregated class \\
\hline $\begin{array}{l}\text { Intensive arable farming } \\
\text { Intensive agroforestry mosaic } \\
\text { Intensive farming } \\
\text { Mixed farming }\end{array}$ & $\begin{array}{l}\text { Intensively farmed } \\
\text { Combinations of intensively farmed, intensively grass, managed forest } \\
\text { Combinations of intensively farmed, intensively grass } \\
\text { Combinations of intensively farmed, intensively grass, extensively grass }\end{array}$ & Intensive agriculture \\
\hline $\begin{array}{l}\text { Managed forestry } \\
\text { Mixed forest }\end{array}$ & $\begin{array}{l}\text { Managed forest } \\
\text { Combinations of managed forest, unmanaged forest }\end{array}$ & Forestry \\
\hline $\begin{array}{l}\text { Mixed pastoral farming } \\
\text { Extensive agroforestry mosaic } \\
\text { Peri-urban }\end{array}$ & $\begin{array}{l}\text { Combinations of intensively grass, extensively grass, very extensively grass } \\
\text { Combinations of extensively grass, very extensively grass, managed forest } \\
\text { Any combination with }>40 \% \text { urban area }\end{array}$ & Extensive agriculture \\
\hline $\begin{array}{l}\text { Intensive pastoral farming } \\
\text { Extensive pastoral farming }\end{array}$ & $\begin{array}{l}\text { Intensively grass } \\
\text { Extensively grass }\end{array}$ & Pastoral agriculture \\
\hline $\begin{array}{l}\text { Very extensive pastoral farming } \\
\text { Multifunctional } \\
\text { Minimal management }\end{array}$ & $\begin{array}{l}\text { Very extensively grass } \\
\text { Four or more land uses in uncommon combination } \\
\text { Combinations of very extensively grass, unmanaged forest, unmanaged land }\end{array}$ & Very extensive management \\
\hline $\begin{array}{l}\text { Unmanaged land } \\
\text { Unmanaged forest } \\
\text { Urban }\end{array}$ & $\begin{array}{l}\text { Unmanaged land } \\
\text { Unmanaged forest } \\
\text { Urban }\end{array}$ & Other/no management \\
\hline
\end{tabular}




\section{Appendix B: Complete territorial scenario results}

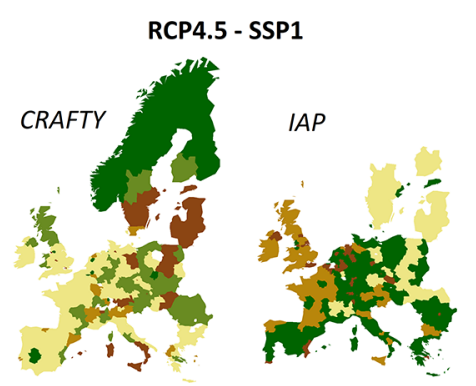

RCP2.6 - SSP1

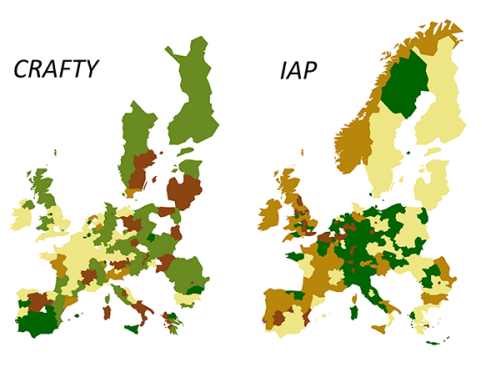

RCP8.5 - SSP3

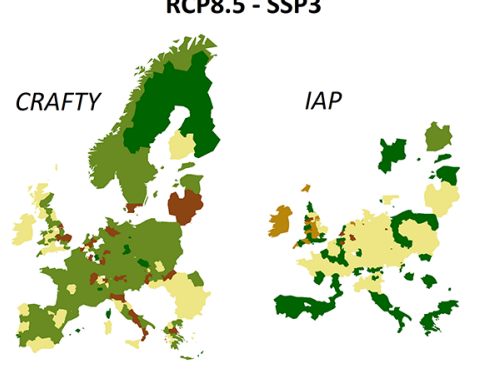

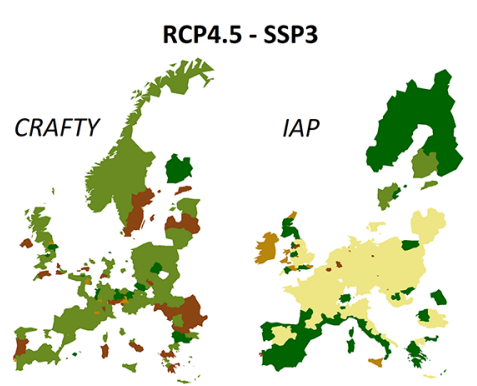

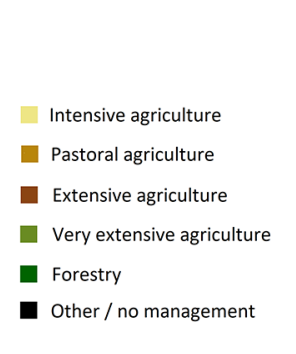

Figure B1. Spatialised differences between the models' results for each scenario at NUTS2 level. Colours identify the most over-represented land use type in each region in the CRAFTY and IAP results relative to the result of the other model. White is shown where no land use type has an over-representation of more than $5 \%$ of the region's cells. 
Code availability. The full model code for CRAFTY-EU is available for download and visualisation via https://landchange.earth/ CRAFTY (last access: 19 February 2021) (Seo et al., 2019). The IAP is available for interactive online runs at http://www. impressions-project.eu/show/IAP2_14855 (last access: 19 February 2021) (IMPRESSIONS Project, 2019), but the model code is not available because the IAP utilises meta-models of several other stand-alone models under different ownership.

Data availability. The full model data for CRAFTY-EU are available for download and visualisation via https://landchange.earth/ CRAFTY (last access: 19 February 2021) (Seo et al., 2019). IAP data are available at http://www.impressions-project.eu/show/ IAP2_14855 (last access: 19 February 2021) (IMPRESSIONS Project, 2019).

Author contributions. CB performed the analysis and drafted the paper. IH and MR assisted with planning, interpretation and writing.

Competing interests. The authors declare that they have no conflict of interest.

Acknowledgements. This research was supported by the EU Seventh Framework Programme project IMPRESSIONS (grant no. 603416) and the Helmholtz Association. We acknowledge support by the KIT-Publication Fund of the Karlsruhe Institute of Technology. We thank Robert Huber, Helen Briassoulis and one anonymous referee for their detailed and helpful reviews of the paper.

Financial support. This research has been supported by the EU 7th Framework Programme (grant no. 603416) and the Helmholtz Association.

The article processing charges for this open-access publication were covered by a Research

Centre of the Helmholtz Association.

Review statement. This paper was edited by Gabriele Messori and reviewed by Robert Huber, Helen Briassoulis, and one anonymous referee.

\section{References}

Alexander, P., Prestele, R., Verburg, P. H., Arneth, A., Baranzelli, C., Batista e Silva, F., Brown, C., Butler, A., Calvin, K., Dendoncker, N., Doelman, J. C., Dunford, R., Engström, K., Eitelberg, D., Fujimori, S., Harrison, P. A., Hasegawa, T., Havlik, P., Holzhauer, S., Humpenöder, F., Jacobs-Crisioni, C., Jain, A. K., Krisztin, T., Kyle, P., Lavalle, C., Lenton, T., Liu, J., Meiyappan, P., Popp, A., Powell, T., Sands, R. D., Schaldach, R., Stehfest, E., Steinbuks, J., Tabeau, A., van Meijl, H., Wise, M. A., and Rounsevell, M. D. A.: Assessing uncertainties in land cover projections, Global Change Biol., 23, 767-781, https://doi.org/10.1111/gcb.13447, 2017.

Appel, F. and Balmann, A.: Human behaviour versus optimising agents and the resilience of farms - Insights from agent-based participatory experiments with FarmAgriPoliS, Ecol. Complex., 40, 100731, https://doi.org/10.1016/j.ecocom.2018.08.005, 2019.

Arneth, A., Brown, C., and Rounsevell, M. D. A.: Global models of human decision-making for land-based mitigation and adaptation assessment, Nat. Clim. Change, 4, 550-557, https://doi.org/10.1038/nclimate2250, 2014.

Audsley, E., Trnka, M., Sabaté, S., Maspons, J., Sanchez, A., Sandars, D., Balek, J., and Pearn, K.: Interactively modelling land profitability to estimate European agricultural and forest land use under future scenarios of climate, socioeconomics and adaptation, Climatic Change, 128, 215-227, https://doi.org/10.1007/s10584-014-1164-6, 2015.

Baldos, C. and Hertel, T. W.: Looking back to move forward on model validation: insights from a global model of agricultural land use Related content Climate adaptation as mitigation: the case of agricultural investments, Environ. Res. Lett., 8, 034024 , https://doi.org/10.1088/1748-9326/8/3/034024, 2013.

Brown, C., Brown, E., Murray-Rust, D., Cojocaru, G., Savin, C., and Rounsevell, M.: Analysing uncertainties in climate change impact assessment across sectors and scenarios, Climatic Change, 128, 293-306, https://doi.org/10.1007/s10584014-1133-0, 2014a.

Brown, C., Murray-Rust, D., Van Vliet, J., Alam, S. J., Verburg, P. H., and Rounsevell, M. D.: Experiments in globalisation, food security and land use decision making, PLoS One, 9, e114213, https://doi.org/10.1371/journal.pone.0114213, 2014b.

Brown, C., Brown, K., and Rounsevell, M.: A philosophical case for process-based modelling of land use change, Model. Earth Syst. Environ., 2, 1-12, https://doi.org/10.1007/s40808-016-0102-1, 2016.

Brown, C., Alexander, P., Holzhauer, S., and Rounsevell, M. D. A.: Behavioral models of climate change adaptation and mitigation in land-based sectors, Wiley Interdisciplin. Rev.: Clim. Change, 8, e448, https://doi.org/10.1002/wcc.448, 2017.

Brown, C., Alexander, P., and Rounsevell, M.: Empirical evidence for the diffusion of knowledge in land use change, J. Land Use Sci., 13, 269-283, https://doi.org/10.1080/1747423X.2018.1515995, 2018a.

Brown, C., Holzhauer, S., Metzger, M. J., Paterson, J. S., and Rounsevell, M.: Land managers' behaviours modulate pathways to visions of future land systems, Reg. Environ. Change, 18, 831-845, https://doi.org/10.1007/s10113-016-0999-y, 2018b. 
Brown, C., Alexander, P., Arneth, A., Holman, I., and Rounsevell, M.: Achievement of Paris climate goals unlikely due to time lags in the land system, Nat. Clim. Change, 9, 203-208, https://doi.org/10.1038/s41558-019-0400-5, 2019a.

Brown, C., Seo, B., and Rounsevell, M.: Societal breakdown as an emergent property of large-scale behavioural models of land use change, Earth Syst. Dynam., 10, 809-845, https://doi.org/10.5194/esd-10-809-2019, 2019b.

Castella, J.-C. and Verburg, P. H.: Combination of processoriented and pattern-oriented models of land-use change in a mountain area of Vietnam, Ecol. Model., 202, 410-420, https://doi.org/10.1016/j.ecolmodel.2006.11.011, 2007.

Chouinard, H. H., Paterson, T., Wandschneider, P. R., and Ohler, A. M.: Will farmers trade profits for stewardship? Heterogeneous motivations for farm practice selection, Land Econ., 84, 66-82, https://doi.org/10.3368/le.84.1.66, 2008.

Couclelis, H.: Modeling frameworks, paradigms, and approaches, in: Geogr. Inf. Syst. Environ. Model., Prentice Hall, London, 2002.

de Coninck, H., Revi, A., Babiker, M., Bertoldi, P., Buckeridge, M., Cartwright, A., Dong, W., Ford, J., Fuss, S., and Hourcade, J.C.: Chapter 4: Strengthening and Implementing the Global Response, available at: http://pure.iiasa.ac.at/id/eprint/15516/ (last access: 19 February 2021), 2018.

Elsawah, S., Guillaume, J. H. A., Filatova, T., Rook, J., and Jakeman, A. J.: A methodology for eliciting, representing, and analysing stakeholder knowledge for decision making on complex socio-ecological systems: From cognitive maps to agent-based models, J. Environ. Manage., 151, 500-516, https://doi.org/10.1016/j.jenvman.2014.11.028, 2015.

Elsawah, S., Filatova, T., Jakeman, A. J., Kettner, A. J., Zellner, M. L., Athanasiadis, I. N., Hamilton, S. H., Axtell, R. L., Brown, D. G., Gilligan, J. M., Janssen, M. A., Robinson, D. T., Rozenberg, J., Ullah, I. I. T., and Lade, S. J.: Eight grand challenges in socio-environmental systems modeling, Socio-Environm. Syst. Model., 2, 16226, https://doi.org/10.18174/sesmo.2020a16226, 2020.

Estoque, R. C., Ooba, M., Togawa, T., and Hijioka, Y.: Projected land-use changes in the Shared Socioeconomic Pathways: Insights and implications, Ambio, 49, 1972-1981, https://doi.org/10.1007/s13280-020-01338-4, 2020.

Filatova, T., Verburg, P. H., Parker, D. C., and Stannard, C. A.: Spatial agent-based models for socio-ecological systems: Challenges and prospects, Environ. Model. Softw., 45, 1-7, https://doi.org/10.1016/j.envsoft.2013.03.017, 2013.

Filatova, T., Polhill, J. G., and van Ewijk, S.: Regime shifts in coupled socio-environmental systems: Review of modelling challenges and approaches, Environ. Model. Softw., 75, 333-347, 2016.

Fonoberova, M., Fonoberov, V. A., and Mezić, I.: Global sensitivity/uncertainty analysis for agentbased models, Reliab. Eng. Syst. Safe., 118, 8-17, https://doi.org/10.1016/j.ress.2013.04.004, 2013.

Fronzek, S., Carter, T. R., Pirttioja, N., Alkemade, R., Audsley, E., Bugmann, H., Flörke, M., Holman, I., Honda, Y., Ito, A., Janes-Bassett, V., Lafond, V., Leemans, R., Mokrech, M., Nunez, S., Sandars, D., Snell, R., Takahashi, K., Tanaka, A., Wimmer, F., and Yoshikawa, M.: Determining sectoral and regional sensitivity to climate and socio-economic change in Europe using impact response surfaces, Reg. Environ. Change, 19, 679-693, https://doi.org/10.1007/s10113-018-1421-8, 2019.

Gostoli, U. and Silverman, E.: Sound behavioural theories, not data, is what makes computational models useful. Review of Artificial Societies and Social Simulation, available at: https://rofasss.org/ 2020/04/22/sound-behavioural-theories/ (last access: 19 February 2021), 2020.

Hamilton, H., Henry, R., Rounsevell, M., Moran, D., Cossar, F., Allen, K., Boden, L., and Alexander, P.: Exploring global food system shocks, scenarios and outcomes, Futures, 123, 102601, https://doi.org/10.1016/j.futures.2020.102601, 2020.

Harrison, P. A., Holman, I. P., and Berry, P. M.: Assessing crosssectoral climate change impacts, vulnerability and adaptation: an introduction to the CLIMSAVE project, Climatic Change, 128, 153-167, https://doi.org/10.1007/s10584-015-1324-3, 2015.

Harrison, P. A., Dunford, R. W., Holman, I. P., and Rounsevell, M. D. A.: Climate change impact modelling needs to include cross-sectoral interactions, Nat. Clim. Change, 6, 885-890, https://doi.org/10.1038/nclimate3039, 2016.

Harrison, P. A., Hauck, J., Austrheim, G., Brotons, L., Cantele, M., Claudet, J., and Turok, J.: Chapter 5: Current and future interactions between nature and society, in: The IPBES regional assessment report on biodiversity and ecosystem services for Europe and Central Asia, edited by: Rounsevell, M., Fischer, M., TorreMarin Rando, A., and Mader, A., IPBES Secretariat, Bonn, Germany, 571-658, 2018.

Harrison, P. A., Dunford, R. W., Holman, I. P., Cojocaru, G., Madsen, M. S., Chen, P. Y., Pedde, S., and Sandars, D.: Differences between low-end and high-end climate change impacts in Europe across multiple sectors, Reg. Environ. Change, 19, 695-709, https://doi.org/10.1007/s10113-018-1352-4, 2019.

Holman, I., Audsley, E., Berry, P., Brown, C., Bugmann, H., Clarke, L., Cojocaru, G., Dunford, R., Fronzek, S., Harrison, P. A., Honda, Y., Janes, V., Kovats, S., Lafond, V., Lobanova, A., Madsen, M. S., Mokrech, M., Nunez, S., Savin, C., and Wimmer, F.: Modelling Climate Change Impacts, Adaptation and Vulnerability in Europe: IMPRESSIONS project deliverable, IMPRESSIONS project, 2017a.

Holman, I. P., Brown, C., Janes, V., and Sandars, D.: Can we be certain about future land use change in Europe? A multiscenario, integrated-assessment analysis, Agric. Syst., 151, 126135, https://doi.org/10.1016/j.agsy.2016.12.001, 2017 b.

Holzhauer, S., Brown, C., and Rounsevell, M.: Modelling dynamic effects of multi-scale institutions on land use change, Reg. Environ. Change, 19, 733-746, https://doi.org/10.1007/s10113-0181424-5, 2019.

Houet, T., Schaller, N., Castets, M., and Gaucherel, C.: Improving the simulation of fine-resolution landscape changes by coupling top-down and bottom-up land use and cover changes rules, Int. J. Geogr. Inf. Sci., 28, 1848-1876, https://doi.org/10.1080/13658816.2014.900775, 2014.

Huber, R., Bakker, M., Balmann, A., Berger, T., Bithell, M., Brown, C., Grêt-Regamey, A., Xiong, H., Le, Q. B., Mack, G., Meyfroidt, P., Millington, J., Müller, B., Polhill, J. G., Sun, Z., Seidl, R., Troost, C., and Finger, R.: Representation of decisionmaking in European agricultural agent-based models, Agric. Syst., 167, 143-160, 2018.

IMPRESSIONS Project: IMPRESSIONS Integrated Assessment Platform version 2 (IAP2), available at: 
http://www.impressions-project.eu/show/IAP2_14855 (last access: 19 February 2021), 2019.

Kay, S., Graves, A., Palma, J. H. N., Moreno, G., RocesDíaz, J. V., Aviron, S., Chouvardas, D., Crous-Duran, J., Ferreiro-Domínguez, N., García de Jalón, S., Măcicăşan, V., Mosquera-Losada, M. R., Pantera, A., Santiago-Freijanes, J. J., Szerencsits, E., Torralba, M., Burgess, P. J., and Herzog, F.: Agroforestry is paying off - Economic evaluation of ecosystem services in European landscapes with and without agroforestry systems, Ecosyst. Serv., 36, 100896, https://doi.org/10.1016/J.ECOSER.2019.100896, 2019.

Kebede, A. S., Dunford, R., Mokrech, M., Audsley, E., Harrison, P. A., Holman, I. P., Nicholls, R. J., Rickebusch, S., Rounsevell, M. D. A., Sabaté, S., Sallaba, F., Sanchez, A., Savin, C., Trnka, M., and Wimmer, F.: Direct and indirect impacts of climate and socio-economic change in Europe: a sensitivity analysis for key land- and water-based sectors, Climatic Change, 128, 261-277, https://doi.org/10.1007/s10584-014-1313-y, 2015.

Kling, C. L., Arritt, R. W., Calhoun, G., and Keiser, D. A.: Integrated Assessment Models of the Food, Energy, and Water Nexus: A Review and an Outline of Research Needs, Annu. Rev. Resour. Econ., 9, 143-163, 2017.

Kok, K., Pedde, S., Gramberger, M., Harrison, P. A., and Holman, I. P.: New European socio-economic scenarios for climate change research: operationalising concepts to extend the shared socio-economic pathways, Reg. Environ. Change, 19, 643-654, https://doi.org/10.1007/s10113-018-1400-0, 2019.

Lawrence, D. M., Hurtt, G. C., Arneth, A., Brovkin, V., Calvin, K. V., Jones, A. D., Jones, C. D., Lawrence, P. J., de NobletDucoudré, N., Pongratz, J., Seneviratne, S. I., and Shevliakova, E.: The Land Use Model Intercomparison Project (LUMIP) contribution to CMIP6: rationale and experimental design, Geosci. Model Dev., 9, 2973-2998, https://doi.org/10.5194/gmd-9-29732016, 2016.

Ligmann-Zielinska, A., Church, R., and Jankowski, P.: Spatial optimization as a generative technique for sustainable multiobjective land-use allocation, Int. J. Geogr. Inf. Sci., 22, 601-622, https://doi.org/10.1080/13658810701587495, 2008.

Ligmann-Zielinska, A., Kramer, D. B., Cheruvelil, K. S., and Soranno, P. A.: Using uncertainty and sensitivity analyses in socioecological agent-based models to improve their analytical performance and policy relevance, PLoS One, 9, e109779, https://doi.org/10.1371/journal.pone.0109779, 2014.

Low, S. and Schäfer, S.: Is bio-energy carbon capture and storage (BECCS) feasible? The contested authority of integrated assessment modeling, Energ. Res. Soc. Sci., 60, 101326, https://doi.org/10.1016/j.erss.2019.101326, 2020.

Meiyappan, P., Dalton, M., O'Neill, B. C., and Jain, A. K.: Spatial modeling of agricultural land use change at global scale, Ecol. Model., 291, 152-174, https://doi.org/10.1016/j.ecolmodel.2014.07.027, 2014.

Meyfroidt, P., Chowdhury, R., de Bremond, A., Ellis, E. C., Erb, K.-H., Filatova, T., Garrett, R. D., Grove, J. M., Heinimann, A., Kuemmerle, T., Kull, C. A., Lambin, E. F., Landon, Y., le Polain de Waroux, Y., Messerli, P., Müller, D., Nielsen, J. Ø., Peterson, G. D., Rodriguez García, V., Schlüter, M., Turner, B. L., and Verburg, P. H.: Middle-range theories of land system change, Global Environ. Change, 53, 52-67, 2018.
Millington, J. D. A., Demeritt, D., and RomeroCalcerrada, R.: Participatory evaluation of agentbased land-use models, J. Land Use Sci., 6, 195-210, https://doi.org/10.1080/1747423X.2011.558595, 2011.

Müller, B., Balbi, S., Buchmann, C. M., de Sousa, L., Dressler, G., Groeneveld, J., Klassert, C. J., Le, Q. B., Millington, J. D. A., Nolzen, H., Parker, D. C., Polhill, J. G., Schlüter, M., Schulze, J., Schwarz, N., Sun, Z., Taillandier, P., and Weise, H.: Standardised and transparent model descriptions for agent-based models: Current status and prospects, Environ. Model. Softw., 55, 156-163, https://doi.org/10.1016/j.envsoft.2014.01.029, 2014.

Müller, B., Hoffmann, F., Heckelei, T., Müller, C., Hertel, T. W., Polhill, J. G., van Wijk, M., Achterbosch, T., Alexander, P., Brown, C., Kreuer, D., Ewert, F., Ge, J., Millington, J. D. A., Seppelt, R., Verburg, P. H., and Webber, H.: Modelling food security: Bridging the gap between the micro and the macro scale, Global Environ. Change, 63, 102085, https://doi.org/10.1016/j.gloenvcha.2020.102085, 2020.

Murray-Rust, D., Brown, C., van Vliet, J., Alam, S. J., Robinson, D. T., Verburg, P. H., and Rounsevell, M.: Combining agent functional types, capitals and services to model land use dynamics, Environ. Model. Softw., 59, 187-201, https://doi.org/10.1016/j.envsoft.2014.05.019, 2014.

Newland, C. P., Maier, H. R., Zecchin, A. C., Newman, J. P., and van Delden, H.: Multi-objective optimisation framework for calibration of Cellular Automata land-use models, Environ. Model. Softw., 100, 175-200, https://doi.org/10.1016/j.envsoft.2017.11.012, 2018.

Obermeister, N.: Local knowledge, global ambitions: IPBES and the advent of multi-scale models and scenarios, Sustainabil. Sci., 14, 843-856, 2019.

O’Neill, B. C., Kriegler, E., Ebi, K. L., Kemp-Benedict, E., Riahi, K., Rothman, D. S., van Ruijven, B. J., van Vuuren, D. P., Birkmann, J., Kok, K., Levy, M., and Solecki, W.: The roads ahead: Narratives for shared socioeconomic pathways describing world futures in the 21st century, Global Environ. Change, 42, 169180, https://doi.org/10.1016/j.gloenvcha.2015.01.004, 2017.

Papadimitriou, L., Holman, I. P., Dunford, R., and Harrison, P. A.: Trade-offs are unavoidable in multi-objective adaptation even in a post-Paris Agreement world, Sci. Total Environ., 696, 134027, https://doi.org/10.1016/j.scitotenv.2019.134027, 2019.

Pedde, S., Kok, K., Hölscher, K., Frantzeskaki, N., Holman, I., Dunford, R., Smith, A., and Jäger, J.: Advancing the use of scenarios to understand society's capacity to achieve the 1.5 degree target, Global Environ. Change, 56, 75-85, https://doi.org/10.1016/J.GLOENVCHA.2019.03.010, 2019.

Polhill, J. G. and Gotts, N. M.: Ontologies for transparent integrated human-natural system modelling, Landsc. Ecol., 24, 1255-1267, https://doi.org/10.1007/s10980-009-9381-5, 2009.

Pongratz, J., Dolman, H., Don, A., Erb, K.-H., Fuchs, R., Herold, M., Jones, C., Kuemmerle, T., Luyssaert, S., Meyfroidt, P., and Naudts, K.: Models meet data: Challenges and opportunities in implementing land management in Earth system models, Global Change Biol., 2, 1470-1487, 2018.

Prestele, R., Alexander, P., Rounsevell, M. D. A., Arneth, A., Calvin, K., Doelman, J., Eitelberg, D. A., Engström, K., Fujimori, S., Hasegawa, T., Havlik, P., Humpenöder, F., Jain, A. K., Krisztin, T., Kyle, P., Meiyappan, P., Popp, A., Sands, R. D., Schaldach, R., Schüngel, J., Stehfest, E., Tabeau, A., 
Van Meijl, H., Van Vliet, J., and Verburg, P. H.: Hotspots of uncertainty in land-use and land-cover change projections: a globalscale model comparison, Global Change Biol., 22, 3967-3983, https://doi.org/10.1111/gcb.13337, 2016.

Rogelj, J., Shindell, D., Jiang, K., Fifita, S., Forster, P., Ginzburg, V., Handa, C., Kheshgi, H., Kobayashi, S., Kriegler, E., Mundaca, L., Séférian, R. and Vilariño, M. V.: Mitigation Pathways Compatible with $1.5^{\circ} \mathrm{C}$ in the Context of Sustainable Development, in: Global Warming of $1.5^{\circ} \mathrm{C}$. An IPCC Special Report on the impacts of global warming of $1.5^{\circ} \mathrm{C}$ above pre-industrial levels and related global greenhouse gas emission pathways, in the context of strengthening the global response to the threat of climate change, edited by: Masson-Delmotte, V., Zhai, P., Pörtner, H.-O., Roberts, D., Skea, P. R., Shukla, J., Pirani, A., Moufouma-Okia, W., Péan, C., Pidcock, R., Connors, S., Matthews, J. B. R., Chen, Y., Zhou, X., Gomis, M. I., Lonnoy, E., Maycock, T., Tignor, V., and Waterfield, T., IPCC Secretariat, Geneva, Switzerland, p. 82, 2018.

Rosa, I. M. D., Ahmed, S. E., and Ewers, R. M.: The transparency, reliability and utility of tropical rainforest land-use and land-cover change models, Global Change Biol., 20, 1707-1722, https://doi.org/10.1111/gcb.12523, 2014.

Salganik, M. J., Lundberg, I., Kindel, A. T., Ahearn, C. E., AlGhoneim, K., Almaatouq, A., Altschul, D. M., Brand, J. E., Carnegie, N. B., Compton, R. J., Datta, D., Davidson, T., Filippova, A., Gilroy, C., Goode, B. J., Jahani, E., Kashyap, R., Kirchner, A., McKay, S., Morgan, A. C., Pentland, A., Polimis, K., Raes, L., Rigobon, D. E., Roberts, C. V., Stanescu, D. M., Suhara, Y., Usmani, A., Wang, E. H., Adem, M., Alhajri, A., AlShebli, B., Amin, R., Amos, R. B., Argyle, L. P., Baer-Bositis, L., Büchi, M., Chung, B.-R., Eggert, W., Faletto, G., Fan, Z., Freese, J., Gadgil, T., Gagné, J., Gao, Y., Halpern-Manners, A., Hashim, S. P., Hausen, S., He, G., Higuera, K., Hogan, B., Horwitz, I. M., Hummel, L. M., Jain, N., Jin, K., Jurgens, D., Kaminski, P., Karapetyan, A., Kim, E. H., Leizman, B., Liu, N., Möser, M., Mack, A. E., Mahajan, M., Mandell, N., Marahrens, H., Mercado-Garcia, D., Mocz, V., Mueller-Gastell, K., Musse, A., Niu, Q., Nowak, W., Omidvar, H., Or, A., Ouyang, K., Pinto, K. M., Porter, E., Porter, K. E., Qian, C., Rauf, T., Sargsyan, A., Schaffner, T., Schnabel, L., Schonfeld, B., Sender, B., Tang, J. D., Tsurkov, E., van Loon, A., Varol, O., Wang, X., Wang, Z., Wang, J., Wang, F., Weissman, S., Whitaker, K., Wolters, M. K., Woon, W. L., Wu, J., Wu, C., Yang, K., Yin, J., Zhao, B., Zhu, C., Brooks-Gunn, J., Engelhardt, B. E., Hardt, M., Knox, D., Levy, K., Narayanan, A., Stewart, B. M., Watts, D. J., and McLanahan, S.: Measuring the predictability of life outcomes with a scientific mass collaboration, P. Natl. Acad. Sci. USA, 117, 201915006, https://doi.org/10.1073/pnas.1915006117, 2020.

Saltelli, A., Aleksankina, K., Becker, W., Fennell, P., Ferretti, F., Holst, N., Li, S., and Wu, Q.: Why so many published sensitivity analyses are false: A systematic review of sensitivity analysis practices, Environ. Model. Softw., 114, 29-39, 2019.

Schwarze, J., Sophie Holst, G., and Mußhoff, O.: Do farmers act like perfectly rational profit maximisers? Results of an extra-laboratory experiment, Int. J. Agric. Manage., 4, 11-20, https://doi.org/10.22004/ag.econ.262336, 2014.
Seo, B., Brown, C., and Rounsevell, M.: Evaluation and calibration of an agent based land use model using remotely sensed land cover and primary productivity data, in: International Geoscience and Remote Sensing Symposium (IGARSS), vol. 2018July, Institute of Electrical and Electronics Engineers Inc., Valencia, 7472-7475, 2018.

Seo, B., Brown, C., and Rounsevell, M.: Competition for Resources between Agent Functional Types (CRAFTY), available at: https: //landchange.earth/CRAFTY (last access: 19 February 2021), 2019.

Seppelt, R., Lautenbach, S., and Volk, M.: Identifying trade-offs between ecosystem services, land use, and biodiversity: A plea for combining scenario analysis and optimization on different spatial scales, Curr. Opin. Environ. Sustain., 5, 458-463, https://doi.org/10.1016/j.cosust.2013.05.002, 2013.

Smith, P., Calvin, K., Nkem, J., Campbell, D., Cherubini, F., Grassi, G., Korotkov, V., Le Hoang, A., Lwasa, S., McElwee, P., Nkonya, E., Saigusa, N., Soussana, J. F., Taboada, M. A., Manning, F. C., Nampanzira, D., Arias-Navarro, C., Vizzarri, M., House, J., Roe, S., Cowie, A., Rounsevell, M., and Arneth, A.: Which practices co-deliver food security, climate change mitigation and adaptation, and combat land degradation and desertification?, Global Change Biol., 26, 1532-1575, 2019.

Sohl, T. L. and Claggett, P. R.: Clarity versus complexity: Land-use modeling as a practical tool fordecision-makers, J. Environ. Manage., 129, 235-243, https://doi.org/10.1016/j.jenvman.2013.07.027, 2013.

Strauch, M., Cord, A. F., Pätzold, C., Lautenbach, S., Kaim, A., Schweitzer, C., Seppelt, R., and Volk, M.: Constraints in multi-objective optimization of land use allocation - Repair or penalize?, Environ. Model. Softw., 118, 241-251, https://doi.org/10.1016/j.envsoft.2019.05.003, 2019.

Turner, P. A., Field, C. B., Lobell, D. B., Sanchez, D. L., and Mach, K. J.: Unprecedented rates of land-use transformation in modelled climate change mitigation pathways, Nat. Sustain., 1, 240245, https://doi.org/10.1038/s41893-018-0063-7, 2018.

van Vliet, J., Bregt, A. K., Brown, D. G., van Delden, H., Heckbert, S., and Verburg, P. H.: A review of current calibration and validation practices in land-change modeling, Environ. Model. Softw., 82, 174-182, 2016.

Verburg, P. H. and Overmars, K. P.: Combining top-down and bottom-up dynamics in land use modeling: exploring the future of abandoned farmlands in Europe with the Dyna-CLUE model, Landsc. Ecol., 24, 1167-1181, https://doi.org/10.1007/s10980009-9355-7, 2009.

Verburg, P. H., Alexander, P., Evans, T., Magliocca, N. R., Malek, Z., Rounsevell, M. D. A., and van Vliet, J.: Beyond land cover change: towards a new generation of land use models, Curr. Opin. Environ. Sustain., 38, 77-85, https://doi.org/10.1016/j.cosust.2019.05.002, 2019. 